\title{
Busyness, Tenure, Meeting Frequency of the CEOs, and Corporate Social Responsibility Disclosure
}

\author{
Melinda Cahyaning Ratri ${ }^{1}$, Iman Harymawan ${ }^{1, *(D)}$ and Khairul Anuar Kamarudin ${ }^{2}$ \\ 1 Department of Accounting, Faculty of Economic and Business, Universitas Airlangga, \\ Jawa Timur 60115, Indonesia; melinda.cahyaning.ratri-2014@feb.unair.ac.id \\ 2 Faculty of Business, University of Wollongong in Dubai, Dubai, United Arab Emirates; \\ KhairulKamarudin@uowdubai.ac.ae \\ * Correspondence: harymawan.iman@feb.unair.ac.id
}

Citation: Ratri, M.C.; Harymawan, I.; Kamarudin, K.A. Busyness, Tenure, Meeting Frequency of the CEOs, and Corporate Social Responsibility Disclosure. Sustainability 2021, 13, 5567. https://doi.org/10.3390/ su13105567

Academic Editor: João Carlos de Oliveira Matias

Received: 12 April 2021

Accepted: 5 May 2021

Published: 17 May 2021

Publisher's Note: MDPI stays neutral with regard to jurisdictional claims in published maps and institutional affiliations.

Copyright: (c) 2021 by the authors. Licensee MDPI, Basel, Switzerland. This article is an open access article distributed under the terms and conditions of the Creative Commons Attribution (CC BY) license (https:// creativecommons.org/licenses/by/ $4.0 /)$.

\begin{abstract}
This study aimed to analyze the relationship between busyness, tenure, and the frequency of CEO meetings and corporate social responsibility (CSR) disclosure. This study used 624 observations from 78 companies listed on the Indonesia Stock Exchange and the Global Reporting Initiative (GRI) database for the 2010-2018 period. This study indicated that companies with busy CEOs or CEOs with long tenure produce fewer CSR disclosures. On the other hand, companies with CEOs who frequently attend board meetings generate more CSR disclosures because they can absorb a lot of useful information to address the changing social and environmental issues. Companies can limit the activities and tenure of the $\mathrm{CEO}$ and increase the awareness of the CEO to attend board meetings to encourage the firm's sustainability. Companies with busy CEOs and long tenure result in less CSR disclosure. Furthermore, the frequency of CEO meetings can enhance CSR disclosure.
\end{abstract}

Keywords: busyness; CEO; corporate social responsibility; meeting frequency; tenure

\section{Introduction}

Currently, the success of a company is not only seen in its economic success [1], but companies must be skilled at balancing the interests of various stakeholders [2]. CSR disclosure is a strategic company effort in bridging the company interests and stakeholders [3]. CSR disclosure is a crucial way to increase transparency [4], accountability [5], reputation [6], company legitimacy [7], awareness of the company's environmental and social practices [8], and its performance [9]. Based on research by the Center for Governance, Institutions, and Organizations of the National University of Singapore (NUS), the quality of CSR disclosure in Indonesia is lower than other ASEAN countries. Indonesia has a 53.6\% value, while the Philippines, Malaysia, Singapore, and Thailand have $56.3 \%, 64.5 \%, 61.7 \%$, and $60.0 \%$. This shows that Indonesia has the lowest level of CSR disclosure compared with other ASEAN countries. Moreover, $53.6 \%$ of public companies in Indonesia disclose CSR information in the annual reports, while the rest of $46.4 \%$ of public companies in Indonesia have no concern in disclosing CSR information in the annual reports. Given the low CSR disclosure level, the government has taken various initiatives to increase corporate awareness through various regulations and awarding entities that care about their sustainability. Thus, it is expected that CSR disclosure will increase.

Strengthening corporate governance is another effort that can increase CSR disclosure. In corporate governance, the president director or Chief Executive Officer (CEO) plays a key role in ensuring that the company can meet its CSR disclosure objectives [10,11]. CEO is the highest leader in company management who has the responsibility of making policies and strategies to achieve organizational goals, supervising and predicting business conditions internally and externally, and making decisions within the organization [12-14]. Based on the upper echelons theory, CEO plays an important role in resource allocation 
and strategic decision making, especially those related to CSR [15]. Thus, the characteristics of the CEO can affect CSR disclosure.

In this study, the characteristics of CEO that were considered included the busyness, tenure, and frequency of $\mathrm{CEO}$ meetings. $\mathrm{CEO}$ busyness is an interesting and important issue in Indonesia, where more than $50 \%$ of CEOs of public companies on the Indonesia Stock Exchange have several positions at other companies [16]. There are two ways of thinking in research related to CEO busyness. The first one is based on the CEO's reputation, expertise, and human capital. The number of other corporate board directorships held by the director indicates the quality and reputation [17]. This is because the CEO has the opportunity to access critical resources that provide benefits for the company through innovations that can increase the benefits of competitive sustainability $[18,19]$. The second one explains that the number of director positions can be a signal of being busy. Busy CEOs will not have enough energy and time to stay focused on their main task of managing and setting company strategy, and thus the company activities will be disrupted [20-23]. In addition, busy CEOs are unable to identify CSR opportunities that can enhance a company's reputation [24,25].

In addition to the number of directorships, $\mathrm{CEO}$ tenure is also an essential characteristic to consider. CEO tenure can show the CEO's work experience and mastery over the job. The longer the CEO's tenure, the more comprehensive the expertise, knowledge, and expertise will be. Thus, it can produce better corporate social performance $[26,27]$ and increase the reputation and trust of stakeholders [28-30]. On the other hand, a longer CEO tenure can cause the company problems because the $\mathrm{CEO}$ will likely be less open-minded, difficult to change, inflexible, and unwilling to take risks [15]. In addition, CEOs with longer tenures are also likely to experience agency conflict problems, and thus they may not be interested in investing in CSR initiatives [31] and tend to produce fewer amounts of corporate social disclosure because long-term relationships can create a reluctance to introduce controversy, which can undermine the long-term sustainability of the company [32,33].

Another characteristic to consider is the CEOs' commitment and responsibilities within the company, which is reflected in the frequency of their meetings. The decisions made by the CEO can be influenced by the number of meetings held [34]. Meeting frequency can result in lower corporate CSR disclosure because the company board is too passive and less focused on their responsibilities [35-37]. On the other hand, the number of board meetings represents various activities related to corporate strategic planning, decision-making processes, accountability, and resource distribution, thereby facilitating the exchange of information between directors to improve sustainable performance $[38,39]$. More frequent board meetings can increase CSR disclosure because it serves as a medium to discuss solutions that can be done to encounter the difficulties that are related to CSR implementation initiatives and the ever-changing concept of CSR [40]. This study analyzed the relationship between busyness, tenure, and the frequency of CEO meetings and CSR disclosure. This study used a sample of all companies listed on the Indonesia Stock Exchange (IDX) and listed in the Global Reporting Initiative (GRI) database for the 20102018 period. This study used ordinary least squares (OLS) regression with a multi-way clustering approach from [41] and a fixed-effect model with STATA 15.0 software to test the hypotheses. This study also conducted several additional tests and robustness analyses to solve endogeneity using the coarsened exact matching method and the Heckman two-stage model.

The results show that companies with busy CEOs and long tenure tend to produce less CSR disclosure. This is because busy CEOs are likely to find it hard to allocate their time and attention optimally in evaluating and understanding CSR-related issues, and thus they cannot appropriately develop a company's CSR disclosure strategy. In addition, CEOs with long tenures tend to avoid risk and feel comfortable in their position and are more concerned with their personal goals, and thus they are reluctant to make changes to achieve the company's sustainability goals. Furthermore, companies with CEOs who frequently attend board meetings tend to produce more CSR disclosures because board meetings can facilitate the CEOs to get more information, ideas, and suggestions to answer various 
problems and issues related to company sustainability. Interestingly, this study found that the company's losses can weaken the negative relationship between CEO busyness and tenure and CSR disclosures and weaken the positive relationship between the frequency of CEO meetings and the company's CSR disclosure.

This study provides several contributions to the literature in corporate governance and sustainability reporting by providing information about the importance of understanding the CEO's characteristics, which includes the CEO's busyness, tenure, and meeting frequency, to encourage CSR disclosure. Furthermore, this study can also support the upper echelons theory by explaining that the characteristics of the CEO reflect the strategic decisions made related to the CSR disclosure strategy. This research also has implications for the company and shareholders when it comes to appointing CEOs and evaluating their roles and responsibilities, where companies can consider limiting the CEO's busyness and tenure, as well as increasing CEO awareness to attend board meetings, in order to strive for the sustainability of the company. Furthermore, for the CSR Rating Agency and the Business Entity Social Responsibility Forum, this research can be considered when understanding, assessing, and predicting the level of CSR disclosure.

This paper is continued with the following structure: Section 2 contains the development of research hypotheses; Section 3 contains explanatory variables, the sample, and research model; Section 4 contains empirical analysis and hypotheses testing results; and Section 5 contains a conclusion of the study, including suggestions for further research.

\section{Literature Review and Hypotheses Development}

\subsection{CSR Disclosure in Indonesia}

CSR is an effort and commitment from the company to positively impact society and other stakeholders over its business processes [42]. Companies must be able to produce products that can provide value-added to society and the environment. In Indonesia, the government has established several regulations to increase awareness of business people regarding CSR. One of them is Law No. 40 of 2007 concerning Limited Liability Companies. Article 74 explains that all companies in the form of limited liability companies operating and/or directly related to natural resources must disclose their social and environmental responsibilities. The law applies to all companies: government, private domestic, and foreign companies. In addition, the Capital Market and Financial Institution Supervisory Agency also issued regulation No. XK6 of 2006 that requires all public companies to disclose activities and costs related to corporate CSR in their financial statements. Government Regulation of the Republic of Indonesia No. 47 of 2012 concerning Social and Environmental Responsibility of Limited Liability Companies also explains that the president director or CEO has full authority and responsibility to implement CSR following the company's annual work plan, which includes the activity plan and the amount of budget required. Thus, the CEO has great control in ensuring that the company has a high CSR disclosure awareness.

Initially, disclosure of CSR in financial reports or sustainability reports was voluntary for management. However, after the issuance of OJK Regulation No. 51/Pojk.03/2017 concerning the Implementation of Sustainable Finance for Financial Services Institutions, Issuers, and Public Companies, all public companies are obliged to prepare a sustainability report, which explains the company's economic, social, and environmental responsibilities. In addition, referring to the Regulation of the Minister of Social Affairs of the Republic of Indonesia No. 6 of 2016 concerning Corporate Social Responsibility in Organizing Social Welfare, the government established a Business Entity Social Responsibility Forum consisting of corporate stakeholders (individuals, business entities, government, and society), which functions to encourage, facilitate, supervise, and/or provide input and suggestions related to the implementation of the company's CSR. Thus, it is expected that more companies will be aware of their CSR disclosures. 


\subsection{CEO Busyness and CSR Disclosure}

The CEO plays an essential role in determining the corporate strategy and assists in obtaining key resources $[12,14]$. A director is considered busy when holding positions in many other organizations or companies [21,43]. Upper echelons theory shows that in a crisis condition, the CEOs will give a different response according to their cognitive aspects and characteristics [15]. Busy CEOs can reduce the company's risk of environmental uncertainty to maintain their reputation [44].

On the other hand, busy CEOs can also interfere with company activities because they cannot manage the company properly due to their limited time [20]. According to [23], busy CEOs may not carry out their functions properly if they serve too many boards. This is because the CEOs have limited time and energy to fulfill their duties adequately $[21,22,25]$. Moreover, busy directors are likely to find it hard to identify CSR disclosure opportunities that can improve the company's reputation [24]. The CEOs' effectiveness in managing the company and formulating strategies is also disrupted if the CEOs are too busy [20,45].

The application of CSR contributes to value creation and competitive advantage for the organization, and thus directors must understand specific issues related to CSR and react quickly to growing businesses [46,47]. CEO busyness can have a negative impact on CSR disclosure. Busy CEOs tend to be unable to pay sufficient and adequate attention to monitoring and evaluating management behavior, understanding CSR-related issues, and attracting important resources that can be used in CSR disclosure strategies. Thus, the proposed hypothesis is:

Hypothesis 1 (H1). Companies with busy CEOs will show less corporate social responsibility disclosure.

\subsection{CEO Tenure and CSR Disclosure}

Upper echelons theory explains that tenure and work experience can influence CEOs' types of actions and decisions [15]. These actions and decisions will be different in each condition (objective situation). On the one hand, CEOs with long tenures have experience, knowledge, and expertise beneficial to the company [27]. On the other hand, when faced with a crisis, CEOs with long tenure do not necessarily understand how to determine the right strategy because they tend to be less flexible [48]. CEO tenure can show the CEO's work experience and mastery over the job. Longer CEO's tenure indicates the diversity of experiences and higher knowledge held, which in turn can produce a favorable balance for its CSR disclosure [33].

Based on OJK Regulation No. 33/Pojk.04/2014 concerning the Board of Directors and Board of Commissioners of Issuers or Public Companies, it is explained that the term of the president director and other boards of directors is a maximum of five years. This presents that the five-year period is the right time to measure the experience and knowledge that the CEO has. CEOs who have long tenures tend to have the potential to cause problems for the company because they will likely be less open-minded, difficult to change, inflexible, and afraid to take risks [48]. CEOs with longer tenures tend to experience agency conflict problems, and thus they may not be interested in investing in CSR initiatives [31]. Moreover, CEOs who have served for a long time will also have a lower number of corporate social disclosures. This happens because long-term relationships with other directors can create a reluctance to introduce controversy and, in turn, can damage the long-term sustainability of the company [32,33].

Several studies have found that CEOs with long tenures tend to prioritize their personal goals more than achieving the company goals [49-51]. Moreover, the experience and knowledge they have about the company provide more control over their work, which causes the CEO to feel comfortable with internal stability and ultimately causes decision making to be slower and based solely on more limited information. Thus, the proposed hypothesis is: 
Hypothesis 2 (H2). Companies with long-tenure CEOs will show less corporate social responsibility disclosure.

\subsection{Frequency of CEO Meetings and CSR Disclosure}

The frequency of CEO meetings is an important dimension that describes the CEO's responsibility in managing the organization [39]. The frequency of board meetings is closely related to board activity in the company and is considered a proxy for board persistence [52]. Board meetings are also an important way of increasing the board's operational effectiveness [53]. The frequency of meetings held can influence the CEO's strategic decisions, including decisions regarding the CSR disclosure strategy [34].

An increase in the frequency of board meetings helps improve governance efficiency [54], and also affects the quality of CSR-related information disclosure [55].

The frequency of board meetings tends to be positively correlated with CSR reporting $[40,56,57]$. This is supported by the fact that CEOs need input and new ideas from their peers to overcome difficulties and problems related to CSR disclosure because the concept of CSR continues to change over time [58]. In addition, the high frequency of meetings also allows directors to supervise better company operations, including CSR reporting activities [37,39].

In practice, board meetings are used as an essential means of resolving business problems related to CSR [59]. CEOs who frequently attend meetings can positively impact CSR disclosure because the higher the frequency of CEO meetings, the more often the CEO will exchange information with other boards of directors to resolve changing issues or problems in the economic, social, and environment fields. Finally, this may encourage CSR disclosure. Thus, the hypothesis proposed in this study is:

Hypothesis 3 (H3). Companies with CEOs who frequently attend board meetings tend to produce more corporate social responsibility disclosure.

\section{Research Methodology}

\subsection{Sample and Data Source}

The sample in this study consisted of all companies listed on the Indonesia Stock Exchange (IDX) and the Global Reporting Initiative (GRI) database for the 2010-2018 period. The data sources were gathered from various sources, including the IDX website, the GRI database, the Bloomberg website, and the ORBIS database. Data related to corporate social responsibility disclosure were obtained through company sustainability reports, both separately or as part of its annual report. Furthermore, data related to CEO characteristics, including total directorships held and the length of tenure of the CEO, were obtained from the Bloomberg website. Data related to the frequency of CEO meetings were obtained through the company's annual reports. Meanwhile, financial data were obtained from the ORBIS database, and data related to corporate governance were obtained through the company's financial and annual reports.

This study applied the following sample selection criteria. First, we excluded companies that were not listed in the GRI database. Second, we excluded missing data for all variables in this study. After applying the sample selection criteria, this study obtained a final sample of 624 observations. For robustness analysis, this study used a sample matching method using coarsened exact matching (CEM) and the Heckman two-stage model. This method is very effective in dealing with potential endogeneity concerns in this study. Several additional tests were also conducted to examine further the relationship between CEO busyness, tenure, and frequency of CEO meetings and CSR disclosure by interacting with the interested variable with company losses and dividing the level of busyness, $\mathrm{CEO}$ tenure, and CEO attendance at board meetings. 


\subsection{Operational Definition of Variables}

The dependent variable in this study was CSR disclosure (CSRD) measured by the CSR disclosure score obtained by dividing the total items disclosed in the sustainability report or annual report by the total items that should be disclosed, based on the GRI index [55]. The number of items disclosed can be seen in the GRI index summary table listed in the sustainability report for companies with a separate sustainability report, while for companies that did not have separate sustainability reports, content analysis was carried out on their annual reports to determine the number of items disclosed. Keywords related to corporate social responsibility were used in this study, referring to several previous studies to increase the validity of the content analysis results [60,61].

In this study, the GRI index used was divided into four categories, namely the GRI Standards index, GRI G.4, GRI G.3.1, and GRI G.3.0 index. The number of items that should be disclosed in the GRI index varies: for GRI G3.0, it is 123 items; for GRI G3.1, 126 items; and for GRI G4, 150 items. As for the GRI Standards, the number of items required was divided into two. For the core option, the number of items required depended on the number of specific topics for each material topic chosen by the company, and thus it varied for each company. For comprehensive options, the number of items required was 147 items. The items selected for each type of GRI index were adjusted based on the provisions of each company. However, if the company did not explain the type of GRI index used, then the index selected was the GRI index that was applied at that period.

Furthermore, the variables of interest in this study were the CEO busyness, tenure, and frequency of CEO meetings. CEO busyness (BUSY) was measured using a dummy variable: the value of 1 if the company had a busy CEO (holding two or more positions in other companies) and 0 otherwise [16]. CEO tenure (TENURE) was measured using a dummy variable, which was given a value of 1 if the CEO's tenure was more than five years and 0 if the tenure of the CEO was less than or equal to five years [16]. The frequency of CEO meetings (MEETING) was measured by dividing the number of meetings attended by the $\mathrm{CEO}$ by the maximum number of meetings held for the company's board of directors in one year [62].

This study used several control variables which are described in detail in the Appendix A, referring to previous research $[31,39,55-57,60,63]$. Several fixed effect variables were also used in this study to accommodate differences in the characteristics of observations including year fixed effects, industry fixed effects, and GRI type fixed effects. The year fixed effect is used to control the differences in economic conditions during the research observation period. Furthermore, industry fixed effect is used to control differences in each industry's characteristics in the study. The GRI type fixed effect is used to control for different types of GRI standards used.

\subsection{Methodology}

This study used the ordinary least squares (OLS) regression model with the multi-way clustering approach from [41] and the fixed effects model to examine the relationship between busyness, tenure, and the frequency of CEO meetings with CSR disclosure. The regression model used to test the hypotheses in this study is formulated in Equation (1). This study expected the BUSY and TENURE coefficients to be negatively related to CSR disclosure, while the MEETING coefficient is expected to be positive for the CSR disclosure.

$$
\begin{gathered}
\text { CSRD }_{i, t}=\beta_{0}+\beta_{1} \text { BUSY }_{i, t}+\beta_{2} \text { TENURE }_{i, t}+\beta_{3} \text { MEETING }_{i, t} \\
+\beta_{4} \text { BOARDSIZE }_{i, t}+\beta_{5} \text { INDCOM }_{i, t}+\beta_{6} \text { BIG }_{i, t}+\beta_{7} \text { FIRMSIZE }_{i, t}+\beta_{8} \text { LEVERAGE }_{i, t} \\
+\beta_{9} \text { FIRMAGE }_{i, t}+\beta_{10} \text { LOSS }_{i, t}+\beta_{11-18 \text { YEAR }_{i, t}}+\beta_{19-25} \text { INDUSTRY }_{i, t}+\beta_{26-28} \\
\text { GRITYPE }_{i, t}+\varepsilon
\end{gathered}
$$




\section{Results}

\subsection{Descriptive Statistics and Univariate Analysis}

Table 1 shows the sample distribution by the industrial sector. The sample in this study was distributed across eight industrial sectors. Panel A shows the sample distribution for companies that have busy CEOs. The greatest number of observations for companies with busy CEOs come from the mining (99), transportation, communication, and utilities (55), and finance, insurance, and real estate industries (54). Furthermore, Panel B shows the sample distribution based on CEO tenure. The results show that the finance, insurance, and real estate industries have the greatest number of observations for companies with CEOs with a service period of more than five years (44), followed by the construction (37) and mining industries (31).

Table 1. Sample distribution.

\begin{tabular}{|c|c|c|c|c|c|c|}
\hline \multicolumn{7}{|c|}{ Panel A: CEO Busyness } \\
\hline Industry & \multicolumn{2}{|c|}{$\begin{array}{c}\text { Company with Busy } \\
\text { CEO }\end{array}$} & \multicolumn{2}{|c|}{$\begin{array}{l}\text { Company without } \\
\text { Busy CEO }\end{array}$} & \multicolumn{2}{|c|}{ Total } \\
\hline & $\mathrm{N}$ & $\%$ & $\mathrm{~N}$ & $\%$ & $\mathrm{~N}$ & $\%$ \\
\hline (SIC 0) Agriculture, Forestry, and Fisheries & 33 & 82.50 & 7 & 17.50 & 40 & 100 \\
\hline (SIC 1) Mining & 99 & 73.88 & 35 & 26.12 & 134 & 100 \\
\hline (SIC 2) Construction & 52 & 61.18 & 33 & 38.82 & 85 & 100 \\
\hline (SIC 3) Manufacturing & 29 & 50.88 & 28 & 49.12 & 57 & 100 \\
\hline (SIC 4) Transportation, Communication, and Utilities & 55 & 70.51 & 23 & 29.49 & 78 & 100 \\
\hline (SIC 5) Wholesale and Retail Trade & 23 & 85.19 & 4 & 14.81 & 27 & 100 \\
\hline (SIC 6) Finance, Insurance, and Real Estate & 54 & 29.19 & 131 & 70.81 & 185 & 100 \\
\hline (SIC 7) Services & 14 & 77.78 & 4 & 22.22 & 18 & 100 \\
\hline Total & 359 & 57.53 & 265 & 42.47 & 624 & 100 \\
\hline \multicolumn{7}{|c|}{ Panel B: CEO Tenure } \\
\hline Industry & \multicolumn{2}{|c|}{$\begin{array}{l}\text { Company with } \\
\text { Long-Tenure CEO }\end{array}$} & \multicolumn{2}{|c|}{$\begin{array}{l}\text { Company with } \\
\text { Short-Tenure CEO }\end{array}$} & & Total \\
\hline & $\mathrm{N}$ & $\%$ & $\mathrm{~N}$ & $\%$ & $\mathrm{~N}$ & $\%$ \\
\hline (SIC 0) Agriculture, Forestry, and Fisheries & 16 & 40.00 & 24 & 60.00 & 40 & 100 \\
\hline (SIC 1) Mining & 31 & 23.13 & 103 & 76.87 & 134 & 100 \\
\hline (SIC 2) Construction & 37 & 43.53 & 48 & 56.47 & 85 & 100 \\
\hline (SIC 3) Manufacturing & 6 & 10.53 & 51 & 89.47 & 57 & 100 \\
\hline (SIC 4) Transportation, Communication, and Utilities & 15 & 19.23 & 63 & 80.77 & 78 & 100 \\
\hline (SIC 5) Wholesale and Retail Trade & 15 & 55.56 & 12 & 44.44 & 27 & 100 \\
\hline (SIC 6) Finance, Insurance, and Real Estate & 44 & 23.78 & 141 & 76.22 & 185 & 100 \\
\hline (SIC 7) Services & 9 & 50.00 & 9 & 50.00 & 18 & 100 \\
\hline Total & 173 & 27.72 & 451 & 72.28 & 624 & 100 \\
\hline
\end{tabular}

Table 2 shows the descriptive statistics of the variables used in this study. The results show that, on average, a company produces CSR disclosures of $42.9 \%$ from the total disclosures provided by the GRI Standards. Then, on average, $57.5 \%$ of companies have busy CEOs, and $27.7 \%$ of companies have CEOs with long tenure (more than five years). Furthermore, the average CEO attends board meetings at $92 \%$. The average board size is 2458. On average, $71.5 \%$ of firms employed Big Four auditors and $11.4 \%$ of firms had a loss in the previous financial year. The average percentage of independent commissioners in the company is $39.6 \%$, and the average age of the company is 3628 . Furthermore, the company has an average company size of 30,748 and leverage of $61.9 \%$. 
Table 2. Sample distribution.

\begin{tabular}{cccccc}
\hline & N & Mean & Median & Minimum & Maximum \\
\hline CSRD & 624 & 0.429 & 0.368 & 0.120 & 1.000 \\
BUSY & 624 & 0.575 & 1.000 & 0.000 & 1.000 \\
TENURE & 624 & 0.277 & 0.000 & 0.000 & 1.000 \\
MEETING & 624 & 92.150 & 97.468 & 50.000 & 100.000 \\
BOARDSIZE & 624 & 2.458 & 2.485 & 1.792 & 2.996 \\
INDCOM & 624 & 39.698 & 40.000 & 0.000 & 80.000 \\
BIG4 & 624 & 0.715 & 1.000 & 0.000 & 1.000 \\
FIRMSIZE & 624 & 30.748 & 30.687 & 26.344 & 34.444 \\
LEVERAGE & 624 & 0.619 & 0.620 & 0.137 & 1.195 \\
FIRMAGE & 624 & 3.628 & 3.714 & 1.609 & 4.779 \\
LOSS & 624 & 0.114 & 0.000 & 0.000 & 1.000 \\
\hline
\end{tabular}

Table 3 displays the results of the Pearson correlation test. The correlation between BUSY and CSRD is positive but not significant. Afterward, the correlation between TENURE and CSRD is negative and significant at the $5 \%$ level. This indicates that companies with longer CEO tenure have less CSR disclosure. Furthermore, the correlation between MEETING and CSRD is positive and significant at the $5 \%$ level, which means that companies with CEOs who frequently attend board meetings will result in more CSR disclosure. Other correlations between the independent variables show significant results and generally do not cause multicollinearity problems for further analysis.

Table 3. Pearson correlations.

\begin{tabular}{|c|c|c|c|c|c|c|c|c|c|c|c|}
\hline & [1] & [2] & [3] & [4] & [5] & [6] & [7] & [8] & [9] & [10] & [11] \\
\hline [1] CSRD & 1.000 & & & & & & & & & & \\
\hline [2] BUSY & $\begin{array}{c}0.013 \\
(0.749)\end{array}$ & 1.000 & & & & & & & & & \\
\hline [3] TENURE & $-\underset{* *}{0.094}$ & $0.148^{* * *}$ & 1.000 & & & & & & & & \\
\hline [4] MEETING & $\begin{array}{c}(0.019) \\
0.079 * * \\
(0.050)\end{array}$ & $\begin{array}{l}(0.000) \\
-0.031 \\
(0.439)\end{array}$ & $\begin{array}{l}-0.058 \\
(0.147)\end{array}$ & 1.000 & & & & & & & \\
\hline [5] BOARDSIZE & $0.223^{* * *}$ & -0.048 & -0.013 & $\underset{* * *}{-0.206}$ & 1.000 & & & & & & \\
\hline [6] INDCOM & $\begin{array}{c}(0.000) \\
-0.074 \text { * } \\
(0.065)\end{array}$ & $\begin{array}{c}(0.230) \\
-0.155 \\
* * * \\
(0.000)\end{array}$ & $\begin{array}{l}-0.016 \\
(0.690)\end{array}$ & $\begin{array}{c}(0.000) \\
-0.146 \\
* * * \\
(0.000)\end{array}$ & $\begin{array}{l}0.073 \text { * } \\
(0.068)\end{array}$ & 1.000 & & & & & \\
\hline [7] BIG4 & $\begin{array}{c}0.182^{* * *} \\
(0.000)\end{array}$ & $\begin{array}{c}0.118^{* * *} \\
(0.003)\end{array}$ & $\begin{array}{l}-0.005 \\
(0.898)\end{array}$ & $\begin{array}{c}-0.081 \\
* * \\
(0.044)\end{array}$ & $\begin{array}{c}0.361^{* * *} \\
(0.000)\end{array}$ & $\begin{array}{l}-0.060 \\
(0.133)\end{array}$ & 1.000 & & & & \\
\hline [8] FIRMSIZE & $\begin{array}{c}0.202^{* * *} \\
(0.000)\end{array}$ & $\begin{array}{c}0.036 \\
(0.363)\end{array}$ & $\begin{array}{c}0.038 \\
(0.340)\end{array}$ & $\begin{array}{c}-0.263 \\
* * * \\
(0.000)\end{array}$ & $\begin{array}{c}0.669^{* * *} \\
(0.000)\end{array}$ & $\begin{array}{c}0.244^{* * *} \\
(0.000)\end{array}$ & $\begin{array}{c}0.385^{* * *} \\
(0.000)\end{array}$ & 1.000 & & & \\
\hline [9] LEVERAGE & $\begin{array}{c}-0.145 \\
* * * \\
(0.000)\end{array}$ & $\begin{array}{c}-0.183 \\
* * * \\
(0.000)\end{array}$ & $\begin{array}{c}0.040 \\
(0.324)\end{array}$ & $\begin{array}{c}-0.191 \\
* * * \\
(0.000)\end{array}$ & $\begin{array}{c}0.098^{* *} \\
(0.015)\end{array}$ & $\begin{array}{c}0.240^{* * *} \\
(0.000)\end{array}$ & $\begin{array}{c}-0.141 \\
* * * \\
(0.000)\end{array}$ & $\begin{array}{c}0.376^{* * *} \\
(0.000)\end{array}$ & 1.000 & & \\
\hline [10] FIRMAGE & $\begin{array}{c}0.112 * * * \\
(0.005)\end{array}$ & $\begin{array}{l}-0.166 \\
* * * \\
(0.000)\end{array}$ & $\begin{array}{l}-0.032 \\
(0.431)\end{array}$ & $\begin{array}{l}-0.129 \\
* * * \\
(0.001)\end{array}$ & $\begin{array}{c}0.245^{* * *} \\
(0.000)\end{array}$ & $\begin{array}{l}-0.000 \\
(0.998)\end{array}$ & $\begin{array}{c}0.043 \\
(0.286)\end{array}$ & $\begin{array}{c}0.176^{* * *} \\
(0.000)\end{array}$ & $\begin{array}{c}0.284^{* * *} \\
(0.000)\end{array}$ & 1.000 & \\
\hline [11] LOSS & $\begin{array}{l}-\underset{* * *}{0.111} \\
(0.005)\end{array}$ & $\begin{array}{c}0.083 \text { ** } \\
(0.038)\end{array}$ & $\begin{array}{l}-0.064 \\
(0.110)\end{array}$ & $\begin{array}{l}0.068 \text { * } \\
(0.088)\end{array}$ & $\begin{array}{c}-0.197 \\
* * * \\
(0.000)\end{array}$ & $\begin{array}{l}-0.023 \\
(0.565)\end{array}$ & $\begin{array}{c}-0.131 \\
* * * \\
(0.001)\end{array}$ & $\begin{array}{c}-0.107 \\
* * * \\
(0.007)\end{array}$ & $\begin{array}{c}0.114^{* * *} \\
(0.004)\end{array}$ & $\begin{array}{l}0.019 \\
(0.639)\end{array}$ & 1.000 \\
\hline
\end{tabular}

Note: $p$-value in parentheses. Asterisks denote statistical significance at the $1 \%\left({ }^{* * *}\right), 5 \%\left({ }^{* *}\right)$, or $10 \%\left(^{*}\right)$ levels, respectively. 
Table 4 presents the results of different tests based on the mean (T-test) and the median (Wilcoxon test). Panel A presents the different test results between companies with and without busy CEOs. The results show that less CSR disclosure generally happens in companies with busy CEOs, but the difference is not significant. Furthermore, Panel B shows the results of different tests between companies and CEOs with long and short tenure. The results show that CSR disclosure is generally lower in companies with CEOs who have longer tenure, and the difference is significant.

Table 4. T-test and Wilcoxon test of CEO busyness and CEO tenure.

\begin{tabular}{|c|c|c|c|c|}
\hline \multicolumn{5}{|c|}{ Panel A: CEO Busyness } \\
\hline & $\begin{array}{l}\text { Company with Busy } \\
\text { CEO }\end{array}$ & $\begin{array}{l}\text { Company without Busy } \\
\text { CEO }\end{array}$ & $\mathrm{t}$-value & z-value \\
\hline CSRD & 0.431 & 0.425 & 0.320 & 0.525 \\
\hline TENURE & 0.334 & 0.200 & $3.739 * * *$ & $3.700 * * *$ \\
\hline MEETING & 91.853 & 92.552 & -0.775 & -0.236 \\
\hline BOARDSIZE & 2.446 & 2.474 & -1.202 & -0.930 \\
\hline INDCOM & 37.748 & 42.341 & $-3.922 * * *$ & $-4.775^{* * *}$ \\
\hline BIG4 & 0.760 & 0.653 & $2.959^{* * *}$ & $2.940^{* * *}$ \\
\hline FIRMSIZE & 30.797 & 30.680 & 0.909 & 1.042 \\
\hline LEVERAGE & 0.583 & 0.667 & $-4.630^{* * *}$ & $-5.408^{* * *}$ \\
\hline FIRMAGE & 3.542 & 3.745 & $-4.200^{* * *}$ & $-4.183^{* * *}$ \\
\hline LOSS & 0.136 & 0.083 & $2.083^{* *}$ & $2.078 * *$ \\
\hline \multicolumn{5}{|c|}{ Panel B: CEO Tenure } \\
\hline & $\begin{array}{l}\text { Company with } \\
\text { Long-Tenure CEO }\end{array}$ & $\begin{array}{c}\text { Company with } \\
\text { Short-Tenure CEO }\end{array}$ & $\mathrm{t}$-value & z-value \\
\hline CSRD & 0.394 & 0.442 & $-2.357^{* *}$ & $-1.726 *$ \\
\hline BUSY & 0.694 & 0.530 & $3.739 * * *$ & 3.700 \\
\hline MEETING & 91.106 & 92.551 & -1.452 & -1.250 \\
\hline BOARDSIZE & 2.452 & 2.461 & -0.328 & -0.225 \\
\hline INDCOM & 39.321 & 39.843 & -0.399 & -1.532 \\
\hline BIG4 & 0.711 & 0.716 & -0.129 & -0.129 \\
\hline FIRMSIZE & 30.845 & 30.710 & 0.955 & 1.027 \\
\hline LEVERAGE & 0.634 & 0.614 & 0.986 & 0.710 \\
\hline FIRMAGE & 3.597 & 3.640 & -0.789 & -1.372 \\
\hline LOSS & 0.081 & 0.126 & -1.602 & -1.600 \\
\hline
\end{tabular}

Note: Asterisks denote statistical significance at the $1 \%\left({ }^{* * *}\right), 5 \%\left({ }^{* *}\right)$, or $10 \%\left(^{*}\right)$ levels, respectively.

\subsection{Busyness, Tenure, Frequency of CEO Meeting, and CSR Disclosure}

Table 5 shows the OLS regression results for busyness, tenure, and the frequency of CEO meetings with company CSR disclosure. Specification (1) shows the relationship between several control variables and CSR disclosure, and the results show a significant relationship and correspond to the predicted direction. In specification (2), the BUSY coefficient value is $-0.037(\mathrm{t}=-2.11)$ and significant at the $5 \%$ level. This indicates that CSR disclosure is higher in the companies with a CEO holding two or more directorships in other companies. Thus, the first hypothesis (H1) is supported. Busy CEOs have limited time and energy to adequately carry out their duties [23,25]. This result is consistent with [24], who explained that the busy directors are unable to identify opportunities for CSR disclosure that can increase the corporate's value and reputation. The CEO's effectiveness in managing the company and formulating strategies is also disrupted if the CEO is too busy $[20,45]$. 
Table 5. CEO busyness, tenure, meeting frequency, and CSR disclosure.

\begin{tabular}{|c|c|c|c|c|c|c|}
\hline & $\begin{array}{l}\text { Predicted } \\
\text { Direction }\end{array}$ & (1) & (2) & $\begin{array}{c}\text { CSRD } \\
(3)\end{array}$ & (4) & (5) \\
\hline BUSY & - & & $\begin{array}{c}-0.037^{* *} \\
(-2.11)\end{array}$ & & & $\begin{array}{c}-0.031 \text { * } \\
(-1.78)\end{array}$ \\
\hline TENURE & - & & & $\begin{array}{l}-0.029 * \\
(-1.96)\end{array}$ & & $\begin{array}{l}-0.022 \\
(-1.55)\end{array}$ \\
\hline MEETING & + & & & & $\begin{array}{c}0.002^{* * *} \\
(3.44)\end{array}$ & $\begin{array}{c}0.002^{* * *} \\
(3.22)\end{array}$ \\
\hline BOARDSIZE & + & $\begin{array}{c}0.074 * * \\
(1.99)\end{array}$ & $\begin{array}{c}0.070 \text { * } \\
(1.88)\end{array}$ & $\begin{array}{c}0.074 * * \\
(1.97)\end{array}$ & $\begin{array}{c}0.079 * * \\
(2.14)\end{array}$ & $\begin{array}{c}0.076^{* *} \\
(2.03)\end{array}$ \\
\hline INDCOM & - & $\begin{array}{l}-0.000 \\
(-0.75)\end{array}$ & $\begin{array}{l}-0.001 \\
(-0.82)\end{array}$ & $\begin{array}{l}-0.000 \\
(-0.76)\end{array}$ & $\begin{array}{l}-0.000 \\
(-0.33)\end{array}$ & $\begin{array}{l}-0.000 \\
(-0.42)\end{array}$ \\
\hline BIG4 & + & $\begin{array}{l}0.022 \\
(1.20)\end{array}$ & $\begin{array}{l}0.021 \\
(1.14)\end{array}$ & $\begin{array}{l}0.020 \\
(1.09)\end{array}$ & $\begin{array}{l}0.021 \\
(1.17)\end{array}$ & $\begin{array}{l}0.019 \\
(1.03)\end{array}$ \\
\hline FIRMSIZE & + & $\begin{array}{c}0.017^{* *} \\
(2.21)\end{array}$ & $\begin{array}{c}0.021 * * * \\
(2.64)\end{array}$ & $\begin{array}{c}0.018 \text { ** } \\
(2.35)\end{array}$ & $\begin{array}{c}0.020 * * * \\
(2.71)\end{array}$ & $\begin{array}{c}0.024^{* * *} \\
(3.14)\end{array}$ \\
\hline LEVERAGE & - & $\begin{array}{c}-0.193^{* * *} \\
(-4.77)\end{array}$ & $\begin{array}{c}-0.197^{* * *} \\
(-4.84)\end{array}$ & $\begin{array}{c}-0.186^{* * *} \\
(-4.57)\end{array}$ & $\begin{array}{c}-0.182 * * * \\
(-4.49)\end{array}$ & $\begin{array}{c}-0.182 * * * \\
(-4.40)\end{array}$ \\
\hline FIRMAGE & + & $\begin{array}{c}0.055^{* * *} \\
(3.48)\end{array}$ & $\begin{array}{c}0.052 * * * \\
(3.27)\end{array}$ & $\begin{array}{c}0.054^{* * *} \\
(3.40)\end{array}$ & $\begin{array}{c}0.059 * * * \\
(3.82)\end{array}$ & $\begin{array}{c}0.055^{* * *} \\
(3.54)\end{array}$ \\
\hline LOSS & - & $\begin{array}{c}-0.043^{* *} \\
(-2.28)\end{array}$ & $\begin{array}{c}-0.040^{* *} \\
(-2.13)\end{array}$ & $\begin{array}{c}-0.046^{* *} \\
(-2.46)\end{array}$ & $\begin{array}{c}-0.044^{* *} \\
(-2.33)\end{array}$ & $\begin{array}{c}-0.045^{* *} \\
(-2.34)\end{array}$ \\
\hline CONSTANT & & $\begin{array}{l}-0.311 \text { * } \\
(-1.78)\end{array}$ & $\begin{array}{c}-0.382 * * \\
(-2.15)\end{array}$ & $\begin{array}{l}-0.336 \text { * } \\
(-1.91)\end{array}$ & $\begin{array}{c}-0.691^{* * *} \\
(-3.58)\end{array}$ & $\begin{array}{c}-0.747^{* * *} \\
(-3.86)\end{array}$ \\
\hline Industry FE & & Included & Included & Included & Included & Included \\
\hline Year FE & & Included & Included & Included & Included & Included \\
\hline GRI Type FE & & Included & Included & Included & Included & Included \\
\hline R-squared & & 0.397 & 0.401 & 0.399 & 0.409 & 0.414 \\
\hline $\mathrm{N}$ & & 624 & 624 & 624 & 624 & 624 \\
\hline
\end{tabular}

Note: $t$ statistics in parentheses. Asterisks denote statistical significance at the $1 \%\left({ }^{* * *}\right), 5 \%\left(^{* *}\right)$, or $10 \%\left(^{*}\right)$ levels, respectively.

Furthermore, specification (3) shows the TENURE coefficient value of $-0.029(t=-1.96)$ which is significant at the $10 \%$ level. This indicates that CSR disclosure is lower in companies with CEOs who have served the company for more than five years, and thus the second hypothesis (H2) is supported. CEOs with long tenures tend to be more concerned with personal goals than achieving company goals [49-51]. The results in this study are also consistent with [31], who explained that CEOs who have served in a company for a long time are more likely to be driven by personal interests and are not interested in investing in CSR initiatives. The long tenure also causes CEOs to be reluctant to introduce controversy in decision making and tend to avoid risk and rely on skills as well as the knowledge they have, which consequently can damage the long-term sustainability of the company [32,33].

In specification (4), the MEETING coefficient value is $0.002(\mathrm{t}=3.44)$ and significant at the $1 \%$ level. The result indicates that companies with CEOs who frequently attend board meetings tend to produce more CSR disclosures, thus supporting the third hypothesis (H3). Increasing the frequency of board meetings can improve governance efficiency, which affects the quality of CRS-related information disclosure [55]. These results are consistent with $[37,40,57]$. They show that the frequency of board meetings tends to be positively correlated with corporate CSR reporting because board meetings allow the CEO to oversee better the company's operational activities, including CSR reporting activities. 


\subsection{Additional Analysis}

This study conducted several additional analyses to examine further the relationship between busyness, tenure, and the frequency of CEO meetings with CSR disclosure. First, this study analyzed how the CEO's busyness, tenure, and frequency of meetings are related to CSR disclosure when the company suffered a loss in the previous financial year. Table 6 shows the results of the interaction regression between BUSY, TENURE, MEETING, and LOSS and CSR disclosure. In specifications (1) and (4), the results show that the coefficient value of BUSY $\times$ LOSS is positive and significant at the level of $1 \%$ and $10 \%$, respectively. This indicates that loss of company weakens the negative relationship between CEO busyness and CSR disclosure. Furthermore, specifications (2) and (4) also show that the TENURE $\times$ LOSS coefficient is positive and significant at the $5 \%$ and $10 \%$ level. These results also indicate that the company's loss weakens the negative relationship between CEO tenure and CSR disclosure. When companies experience losses, the busy and long tenure CEOs will build and attract stakeholder trust through more CSR disclosures. This is done to protect their position and reputation $[17,19]$.

Table 6. Interaction between busyness, tenure, frequency of CEO meeting and company losses.

\begin{tabular}{|c|c|c|c|c|c|}
\hline & $\begin{array}{l}\text { Predicted } \\
\text { Direction }\end{array}$ & (1) & (2) & (3) & (4) \\
\hline BUSYxLOSS & + & $\begin{array}{c}0.094^{* * *} \\
(2.61)\end{array}$ & & & $\begin{array}{c}0.072 * \\
(1.90)\end{array}$ \\
\hline BUSY & - & $\begin{array}{c}-0.048^{* *} \\
(-2.50)\end{array}$ & & & $\begin{array}{c}-0.041^{* *} \\
(-2.13)\end{array}$ \\
\hline TENURExLOSS & + & & $\begin{array}{c}0.102 \text { ** } \\
(2.56)\end{array}$ & & $\begin{array}{c}0.082 * \\
(1.95)\end{array}$ \\
\hline TENURE & - & & $\begin{array}{c}-0.037^{* *} \\
(-2.40)\end{array}$ & & $\begin{array}{c}-0.030 \text { ** } \\
(-1.99)\end{array}$ \\
\hline MEETINGxLOSS & - & & & $\begin{array}{l}-0.003 * \\
(-1.68)\end{array}$ & $\begin{array}{l}-0.002 \\
(-1.49)\end{array}$ \\
\hline MEETING & + & & & $\begin{array}{c}0.003^{* * *} \\
(3.72)\end{array}$ & $\begin{array}{c}0.003^{* * * *} \\
(3.43)\end{array}$ \\
\hline LOSS & - & $\begin{array}{c}-0.103 * * * \\
(-3.59)\end{array}$ & $\begin{array}{c}-0.063^{* * *} \\
(-3.09)\end{array}$ & $\begin{array}{l}0.224 \\
(1.37)\end{array}$ & $\begin{array}{l}0.111 \\
(0.71)\end{array}$ \\
\hline BOARDSIZE & + & $\begin{array}{c}0.073 * \\
(1.96)\end{array}$ & $\begin{array}{c}0.078^{* *} \\
(2.10)\end{array}$ & $\begin{array}{c}0.076^{* *} \\
(2.06)\end{array}$ & $\begin{array}{c}0.079 * * \\
(2.13)\end{array}$ \\
\hline INDCOM & - & $\begin{array}{l}-0.000 \\
(-0.73)\end{array}$ & $\begin{array}{l}-0.000 \\
(-0.65)\end{array}$ & $\begin{array}{l}-0.000 \\
(-0.29)\end{array}$ & $\begin{array}{l}-0.000 \\
(-0.23)\end{array}$ \\
\hline BIG4 & + & $\begin{array}{l}0.023 \\
(1.24)\end{array}$ & $\begin{array}{l}0.018 \\
(0.99)\end{array}$ & $\begin{array}{c}0.023 \\
(1.27)\end{array}$ & $\begin{array}{l}0.020 \\
(1.09)\end{array}$ \\
\hline FIRMSIZE & + & $\begin{array}{c}0.021^{* * *} \\
(2.68)\end{array}$ & $\begin{array}{c}0.018^{* *} \\
(2.37)\end{array}$ & $\begin{array}{c}0.020^{* * *} \\
(2.72)\end{array}$ & $\begin{array}{c}0.025^{* * * *} \\
(3.21)\end{array}$ \\
\hline LEVERAGE & - & $\begin{array}{c}-0.205^{* * *} \\
(-5.01)\end{array}$ & $\begin{array}{c}-0.198^{* * *} \\
(-4.82)\end{array}$ & $\begin{array}{c}-0.186^{* * *} \\
(-4.59)\end{array}$ & $\begin{array}{c}-0.201^{* * * *} \\
(-4.80)\end{array}$ \\
\hline FIRMAGE & + & $\begin{array}{c}0.054^{* * *} \\
(3.33)\end{array}$ & $\begin{array}{c}0.055^{* * *} \\
(3.47)\end{array}$ & $\begin{array}{c}0.060 * * * \\
(3.86)\end{array}$ & $\begin{array}{c}0.057^{* * *} \\
(3.67)\end{array}$ \\
\hline CONSTANT & & $\begin{array}{c}-0.387^{* *} \\
(-2.17)\end{array}$ & $\begin{array}{l}-0.341 \text { * } \\
(-1.94)\end{array}$ & $\begin{array}{c}-0.721^{* * *} \\
(-3.69)\end{array}$ & $\begin{array}{c}-0.783^{* * * *} \\
(-3.99)\end{array}$ \\
\hline Industry FE & & Included & Included & Included & Included \\
\hline Year FE & & Included & Included & Included & Included \\
\hline GRI Type FE & & Included & Included & Included & Included \\
\hline R-squared & & 0.405 & 0.402 & 0.411 & 0.421 \\
\hline $\mathrm{N}$ & & 624 & 624 & 624 & 624 \\
\hline
\end{tabular}

Note: $\mathrm{t}$ statistics in parentheses. Asterisks denote statistical significance at the $1 \%\left({ }^{(* *)}\right), 5 \%\left({ }^{* *}\right)$, or $10 \%\left({ }^{*}\right)$ levels, respectively. 
Moreover, specification (3) demonstrates that the MEETINGxLOSS coefficient is negative and significant at the $10 \%$ level, which means that the company's losses weaken the positive relationship between CEO meeting frequency and CSR disclosure. This indicates that the frequency of meetings will be more focused on discussing causes and solutions related to the company's financial loss, rather than discussing problems associated with CSR disclosure. This is because one of the indicators that can influence decisions in reporting corporate social responsibility activities is sufficient funds to finance CSR activities [64].

Furthermore, the second additional analysis examined how the degree/level of busyness, tenure, and the frequency of CEO meetings is related to the company's CSR disclosure. Based on the previous literature related to board busyness [65-67], it is possible to classify the degree/level of CEO busyness. This study classified the degree of CEO busyness into two segments based on the median value. Referring to [68,69], the level of CEO busyness was classified as 'busy' if the value was below the median (BUSY) and 'very busy' if the value was above the median (VERY_BUSY). Table 7 presents the test results of the two levels of CEO busyness with CSR disclosure. The results show that busy CEOs have a negative and significant relationship with corporate CSR disclosure, while very busy CEOs show insignificant results. This indicates that companies with busy CEOs tend to produce less CSR disclosure.

Table 7. CEO busyness and CSR disclosure—-busy and very busy.

\begin{tabular}{|c|c|c|c|}
\hline & \multirow{2}{*}{ Predicted Direction } & \multicolumn{2}{|c|}{ CSRD } \\
\hline & & (1) & (2) \\
\hline BUSY & - & $\begin{array}{l}-0.030 * \\
(-1.84)\end{array}$ & \\
\hline VERY_BUSY & - & & $\begin{array}{l}0.001 \\
(0.03)\end{array}$ \\
\hline TENURE & - & $\begin{array}{l}-0.026 * \\
(-1.82)\end{array}$ & $\begin{array}{l}-0.025 * \\
(-1.69)\end{array}$ \\
\hline MEETING & + & $\begin{array}{c}0.002^{* * *} \\
(3.31)\end{array}$ & $\begin{array}{c}0.002^{* * *} \\
(3.35)\end{array}$ \\
\hline BOARDSIZE & + & $\begin{array}{c}0.072 * \\
(1.94)\end{array}$ & $\begin{array}{c}0.079 * * \\
(2.12)\end{array}$ \\
\hline INDCOM & - & $\begin{array}{l}-0.000 \\
(-0.41)\end{array}$ & $\begin{array}{l}-0.000 \\
(-0.35)\end{array}$ \\
\hline BIG4 & + & $\begin{array}{l}0.021 \\
(1.14)\end{array}$ & $\begin{array}{l}0.019 \\
(1.07)\end{array}$ \\
\hline FIRMSIZE & + & $\begin{array}{c}0.022^{* * *} \\
(2.99)\end{array}$ & $\begin{array}{c}0.021^{* * * *} \\
(2.75)\end{array}$ \\
\hline LEVERAGE & - & $\begin{array}{c}-0.180^{* * *} \\
(-4.41)\end{array}$ & $\begin{array}{c}-0.177^{* * * *} \\
(-4.32)\end{array}$ \\
\hline FIRMAGE & + & $\begin{array}{c}0.058^{* * *} \\
(3.82)\end{array}$ & $\begin{array}{c}0.058^{* * *} \\
(3.72)\end{array}$ \\
\hline LOSS & - & $\begin{array}{c}-0.046^{* *} \\
(-2.43)\end{array}$ & $\begin{array}{c}-0.047^{* *} \\
(-2.48)\end{array}$ \\
\hline CONSTANT & & $\begin{array}{c}-0.712 * * * \\
(-3.70)\end{array}$ & $\begin{array}{c}-0.702 * * * \\
(-3.58)\end{array}$ \\
\hline Industry FE & & Included & Included \\
\hline Year FE & & Included & Included \\
\hline GRI Type FE & & Included & Included \\
\hline R-squared & & 0.414 & 0.411 \\
\hline $\mathrm{N}$ & & 624 & 624 \\
\hline
\end{tabular}

Note: $\mathrm{t}$ statistics in parentheses. Asterisks denote statistical significance at the $1 \%\left({ }^{* * *}\right), 5 \%\left({ }^{* *}\right)$, or $10 \%\left(^{*}\right)$ levels, respectively. 
This study also observed the level of tenure and frequency of CEO meetings with corporate CSR disclosures. Referring to previous research [70-72], CEO tenure can be classified into several levels to clarify the results. In this analysis, CEO tenure was classified into two segments based on median value, namely 'long tenure' if the value was below the median (LONGER_TENURE) and 'very long tenure' if the value was above the median. (LONGEST_TENURE). Table 8 presents the test results on two levels of CEO tenure with CSR disclosure. The results confirm that CEOs with long tenure have a negative and significant relationship with CSR disclosure, while CEOs with very long tenure have insignificant results.

Table 8. CEO tenure and CSR disclosure-longer-tenure and longest-tenure.

\begin{tabular}{|c|c|c|c|}
\hline & \multirow[b]{2}{*}{ Predicted Direction } & \multicolumn{2}{|c|}{ CSRD } \\
\hline & & (1) & (2) \\
\hline LONGER_TENURE & - & $\begin{array}{c}-0.041^{* *} \\
(-2.20)\end{array}$ & \\
\hline LONGEST_TENURE & - & & $\begin{array}{l}0.012 \\
(0.62)\end{array}$ \\
\hline BUSY & - & $\begin{array}{l}-0.029 * \\
(-1.69)\end{array}$ & $\begin{array}{l}-0.032 * \\
(-1.87)\end{array}$ \\
\hline MEETING & + & $\begin{array}{c}0.002 * * * \\
(3.26)\end{array}$ & $\begin{array}{c}0.002 * * * \\
(3.31)\end{array}$ \\
\hline BOARDSIZE & + & $\begin{array}{c}0.079^{* *} \\
(2.10)\end{array}$ & $\begin{array}{c}0.077^{* *} \\
(2.06)\end{array}$ \\
\hline INDCOM & - & $\begin{array}{l}-0.000 \\
(-0.43)\end{array}$ & $\begin{array}{l}-0.000 \\
(-0.40)\end{array}$ \\
\hline BIG4 & + & $\begin{array}{l}0.019 \\
(1.05)\end{array}$ & $\begin{array}{l}0.020 \\
(1.14)\end{array}$ \\
\hline FIRMSIZE & + & $\begin{array}{c}0.025^{* * *} \\
(3.16)\end{array}$ & $\begin{array}{c}0.024^{* * *} \\
(3.06)\end{array}$ \\
\hline LEVERAGE & - & $\begin{array}{c}-0.189^{* * *} \\
(-4.60)\end{array}$ & $\begin{array}{c}-0.190^{* * *} \\
(-4.49)\end{array}$ \\
\hline FIRMAGE & + & $\begin{array}{c}0.056^{* * *} \\
(3.63)\end{array}$ & $\begin{array}{c}0.057^{* * *} \\
(3.61)\end{array}$ \\
\hline LOSS & - & $\begin{array}{c}-0.045^{* *} \\
(-2.39)\end{array}$ & $\begin{array}{c}-0.041^{* *} \\
(-2.17)\end{array}$ \\
\hline CONTANT & & $\begin{array}{c}-0.766^{* * *} \\
(-3.94)\end{array}$ & $\begin{array}{c}-0.742 * * * \\
(-3.84)\end{array}$ \\
\hline Industry FE & & Included & Included \\
\hline Year FE & & Included & Included \\
\hline GRI Type FE & & Included & Included \\
\hline R-squared & & 0.416 & 0.413 \\
\hline $\mathrm{N}$ & & 624 & 624 \\
\hline
\end{tabular}

Note: $\mathrm{t}$ statistics in parentheses. Asterisks denote statistical significance at the $1 \%\left({ }^{* * *}\right), 5 \%\left({ }^{* *}\right)$, or $10 \%\left({ }^{*}\right)$ levels, respectively.

Furthermore, the level in the CEO meeting frequency was also classified into two segments based on the median value, which were 'rarely attend meetings' if the value was below the median (RARELY_MEETING) and 'frequently attend meetings' if the value was above the median (FREQUENT_MEETING) [73,74]. Table 9 displays the test results of two levels of CEO meeting frequency with CSR disclosure. The results show that CEOs who rarely attend board meetings have a negative and significant relationship with corporate CSR disclosure. In contrast, CEOs who frequently attend board meetings have a positive and significant relationship with CSR disclosure. 
Table 9. Frequency of CEO meeting and CSR disclosure-rare meeting and frequent meeting.

\begin{tabular}{|c|c|c|c|}
\hline & \multirow[b]{2}{*}{ Predicted Direction } & \multicolumn{2}{|c|}{ CSRD } \\
\hline & & (1) & (2) \\
\hline RARELY_MEETING & - & $\begin{array}{c}-0.001 \text { *** } \\
(-2.83)\end{array}$ & \\
\hline FREQUENT_MEETING & + & & $\begin{array}{c}0.001 * * * \\
(3.19)\end{array}$ \\
\hline BUSY & - & $\begin{array}{c}-0.035^{* *} \\
(-2.03)\end{array}$ & $\begin{array}{c}-0.034^{* *} \\
(-1.98)\end{array}$ \\
\hline TENURE & - & $\begin{array}{l}-0.025 * \\
(-1.69)\end{array}$ & $\begin{array}{l}-0.024 \\
(-1.64)\end{array}$ \\
\hline BOARDSIZE & + & $\begin{array}{c}0.070 * \\
(1.89)\end{array}$ & $\begin{array}{c}0.071 * \\
(1.93)\end{array}$ \\
\hline INDCOM & - & $\begin{array}{l}-0.000 \\
(-0.73)\end{array}$ & $\begin{array}{l}-0.000 \\
(-0.64)\end{array}$ \\
\hline BIG4 & + & $\begin{array}{l}0.025 \\
(1.33)\end{array}$ & $\begin{array}{l}0.025 \\
(1.34)\end{array}$ \\
\hline FIRMSIZE & + & $\begin{array}{c}0.025^{* * * *} \\
(3.27)\end{array}$ & $\begin{array}{c}0.026^{* * * *} \\
(3.36)\end{array}$ \\
\hline LEVERAGE & - & $\begin{array}{c}-0.187^{* * *} \\
(-4.51)\end{array}$ & $\begin{array}{c}-0.185^{* * *} \\
(-4.46)\end{array}$ \\
\hline FIRMAGE & + & $\begin{array}{c}0.057^{* * *} \\
(3.63)\end{array}$ & $\begin{array}{c}0.057^{* * *} \\
(3.69)\end{array}$ \\
\hline LOSS & - & $\begin{array}{c}-0.047^{* *} \\
(-2.37)\end{array}$ & $\begin{array}{c}-0.047^{* *} \\
(-2.38)\end{array}$ \\
\hline CONTANT & & $\begin{array}{c}-0.529 * * * \\
(-3.05)\end{array}$ & $\begin{array}{c}-0.607^{* * *} \\
(-3.47)\end{array}$ \\
\hline Industry FE & & Included & Included \\
\hline Year FE & & Included & Included \\
\hline GRI Type FE & & Included & Included \\
\hline R-squared & & 0.412 & 0.414 \\
\hline $\mathrm{N}$ & & 624 & 624 \\
\hline
\end{tabular}

Note: $\mathrm{t}$ statistics in parentheses. Asterisks denote statistical significance at the $1 \%\left({ }^{* * *}\right), 5 \%\left(^{* *}\right)$, or $10 \%\left(^{*}\right)$ levels, respectively.

\subsection{Robustness Analysis}

In this study, there was the potential for an endogeneity problem, in which a busy CEO may hold too many positions outside the company and be unable to make strategic decisions appropriately, thus contributing to less CSR disclosure. Conversely, companies that have less CSR disclosure may find it difficult if they have to recruit directors who have many positions in other companies. Therefore, to strengthen the main findings and overcome the endogeneity (self-selection bias problem) in this study, a robustness test was carried out by adopting the coarsened exact matching (CEM) and the Heckman two-stage model.

In the CEM analysis, we included seven covariates into the model and arranged each covariate into the same five strata. After imposing the matching requirements, the number of observations using a matched sample was 534 observations. Table 10 Panel A provides a summary of matched CEMs. A total of 298 out of 359 observations had busy CEOs matched with 236 out of 265 observations, which did not have busy CEOs. Overall, we found consistent results in the main findings, where CEO busyness and tenure are negatively and significantly related to CSR disclosure, while CEO meeting frequency is positively and significantly related to CSR disclosure. This study also conducted non-tabulated CEM testing using $\mathrm{CEO}$ tenure and meeting frequency as treatment variables and obtained the consistent results. Thus, these findings indicate that the results of this study are robust from the problem of self-selection bias for observable variables. 
Table 10. Busyness, tenure, frequency of CEO meeting, and CSR disclosure-coarsened exact matching method.

\begin{tabular}{|c|c|c|c|c|c|}
\hline \multicolumn{6}{|c|}{ Panel A: Matching Summary } \\
\hline & & \multicolumn{2}{|c|}{ BUSY $=0$} & \multicolumn{2}{|c|}{ BUSY = 1} \\
\hline & & \multicolumn{2}{|c|}{265} & \multicolumn{2}{|c|}{359} \\
\hline \multirow{2}{*}{\multicolumn{2}{|c|}{ Unmatched }} & \multicolumn{2}{|c|}{236} & \multicolumn{2}{|c|}{298} \\
\hline & & \multicolumn{2}{|c|}{29} & \multicolumn{2}{|c|}{61} \\
\hline \multicolumn{6}{|c|}{ Panel B: OLS Regression Results } \\
\hline & Prediction & & & & \\
\hline & Direction & (1) & $(2)$ & (3) & (4) \\
\hline BUSY & - & $\begin{array}{c}-0.044^{* *} \\
(-2.24)\end{array}$ & & & $\begin{array}{c}-0.038^{* *} \\
(-1.97)\end{array}$ \\
\hline TENURE & - & & $\begin{array}{c}-0.053^{* * *} \\
(-3.21)\end{array}$ & & $\begin{array}{c}-0.046 \text { *** } \\
(-2.86)\end{array}$ \\
\hline MEETING & + & & & $\begin{array}{c}0.003^{* * *} \\
(3.40)\end{array}$ & $\begin{array}{c}0.002^{* * *} \\
(3.13)\end{array}$ \\
\hline BOARDSIZE & + & $\begin{array}{c}0.105^{* *} \\
(2.21)\end{array}$ & $\begin{array}{c}0.106^{* *} \\
(2.22)\end{array}$ & $\begin{array}{c}0.113^{* *} \\
(2.38)\end{array}$ & $\begin{array}{c}0.109 * * \\
(2.32)\end{array}$ \\
\hline INDCOM & - & $\begin{array}{l}0.000 \\
(0.30)\end{array}$ & $\begin{array}{l}0.000 \\
(0.50)\end{array}$ & $\begin{array}{l}0.001 \\
(0.78)\end{array}$ & $\begin{array}{l}0.001 \\
(0.80)\end{array}$ \\
\hline BIG4 & + & $\begin{array}{l}0.016 \\
(0.71)\end{array}$ & $\begin{array}{l}0.009 \\
(0.39)\end{array}$ & $\begin{array}{l}0.017 \\
(0.76)\end{array}$ & $\begin{array}{l}0.013 \\
(0.58)\end{array}$ \\
\hline FIRMSIZE & + & $\begin{array}{c}0.022 * * \\
(2.24)\end{array}$ & $\begin{array}{c}0.021^{* *} \\
(2.23)\end{array}$ & $\begin{array}{c}0.019 * * \\
(2.15)\end{array}$ & $\begin{array}{c}0.027^{* * *} \\
(2.84)\end{array}$ \\
\hline LEVERAGE & - & $\begin{array}{c}-0.269 * * * \\
(-4.70)\end{array}$ & $\begin{array}{c}-0.255^{* * *} \\
(-4.52)\end{array}$ & $\begin{array}{c}-0.250^{* * *} \\
(-4.35)\end{array}$ & $\begin{array}{c}-0.257^{* * *} \\
(-4.49)\end{array}$ \\
\hline FIRMAGE & + & $\begin{array}{c}0.046^{* *} \\
(2.45)\end{array}$ & $\begin{array}{c}0.049^{* * *} \\
(2.60)\end{array}$ & $\begin{array}{c}0.054^{* * *} \\
(2.92)\end{array}$ & $\begin{array}{c}0.049^{* * *} \\
(2.68)\end{array}$ \\
\hline LOSS & - & $\begin{array}{c}-0.077 * * \\
(-2.33)\end{array}$ & $\begin{array}{c}-0.084^{* * *} \\
(-2.62)\end{array}$ & $\begin{array}{c}-0.078 \text { ** } \\
(-2.44)\end{array}$ & $\begin{array}{c}-0.090^{* * *} \\
(-2.80)\end{array}$ \\
\hline CONSTANT & & $\begin{array}{c}-0.438^{* *} \\
(-2.03)\end{array}$ & $\begin{array}{c}-0.433 \text { ** } \\
(-2.07)\end{array}$ & $\begin{array}{c}-0.727^{* * *} \\
(-3.24)\end{array}$ & $\begin{array}{c}-0.848^{* * *} \\
(-3.76)\end{array}$ \\
\hline Industry FE & & Included & Included & Included & Included \\
\hline Year FE & & Included & Included & Included & Included \\
\hline GRI Type FE & & Included & Included & Included & Included \\
\hline R-squared & & 0.392 & 0.394 & 0.400 & 0.411 \\
\hline $\mathrm{N}$ & & 534 & 534 & 534 & 534 \\
\hline
\end{tabular}

Note: $\mathrm{t}$ statistics in parentheses. Asterisks denote statistical significance at the $1 \%\left({ }^{* * *}\right), 5 \%\left(^{* *}\right)$, or $10 \%\left(^{*}\right)$ levels, respectively.

Furthermore, this study also conducted tests using the Heckman two-stage model. To perform this analysis, an instrument variable is required, which must be related to the suspected endogenous variable but not associated with the error term of the dependent variable [75]; thus, in this study, the instrument variable must be related to BUSY but not related to CSRD. Referring to [66,76,77], the instrument variables used in this study were DISTANCE and CEOAGE. The DISTANCE variable was measured by the natural logarithm of the distance between the company's head office and the largest airport in the city where the company's head office is located. In addition, the CEOAGE variable was measured using a dummy variable, where the value was 1 if the CEO age was more than or equal to 60 years and 0 if otherwise. Table 11 Panel A presents the results of Heckman's first-stage regression estimation. Next, Panel B presents the estimation results of Heckman's secondstage regression for the CSR disclosure model. The results display that the BUSY coefficient remains negatively and significantly related to several levels throughout the specifications. However, the TENURE coefficient shows that there is no significant relationship with CSRD, except for specification (2): the TENURE coefficient value is negatively related and significant at level $10 \%$. Furthermore, the MEETING coefficient still shows a positive and significant relationship at the $1 \%$ level for all specifications. Thus, overall, the results in Table 11 support the main results presented in Table 5 and show that the main results in this model are robust to the problem of self-selection bias for unobservable variables. 
Table 11. Busyness, tenure, frequency of CEO meeting, and CSR disclosure-Heckman two-stage model.

\begin{tabular}{|c|c|c|c|}
\hline \multicolumn{4}{|c|}{ Panel A: First-Stage Regression Model } \\
\hline & \multicolumn{3}{|c|}{ BUSY } \\
\hline \multirow{3}{*}{ DISTANCE } & (1) & $(2)$ & (3) \\
\hline & $-0.557^{* * *}$ & & $-0.569^{* * *}$ \\
\hline & $(-4.13)$ & & $(-4.13)$ \\
\hline \multirow[t]{2}{*}{ CEO_AGE } & & $-0.293^{* *}$ & $-0.336^{* *}$ \\
\hline & & $(-1.99)$ & $(-2.26)$ \\
\hline \multirow[t]{2}{*}{ BOARDSIZE } & -0.273 & -0.457 & -0.250 \\
\hline & $(-0.87)$ & $(-1.58)$ & $(-0.81)$ \\
\hline \multirow[t]{2}{*}{ INDCOM } & -0.004 & -0.003 & -0.003 \\
\hline & $(-0.82)$ & $(-0.60)$ & $(-0.68)$ \\
\hline \multirow[t]{2}{*}{ BIG4 } & -0.047 & -0.082 & -0.072 \\
\hline & $(-0.31)$ & $(-0.54)$ & $(-0.47)$ \\
\hline \multirow[t]{2}{*}{ FIRMSIZE } & $0.352 * * *$ & $0.377^{* * *}$ & $0.355^{* * *}$ \\
\hline & $(5.50)$ & $(6.08)$ & $(5.52)$ \\
\hline \multirow[t]{2}{*}{ LEVERAGE } & -0.369 & -0.399 & -0.372 \\
\hline & $(-1.03)$ & $(-1.14)$ & $(-1.05)$ \\
\hline FIRMAGE & $-0.273^{* * *}$ & $-0.267^{* * *}$ & -0.272 *** \\
\hline LOSS & (1.17) & $(0.60)$ & $(0.87)$ \\
\hline \multirow[t]{2}{*}{ CONSTANT } & $-6.236^{* * *}$ & $-8.169^{* * *}$ & $-6.294^{* * *}$ \\
\hline & $(-3.94)$ & $(-5.56)$ & $(-3.99)$ \\
\hline Industry FE & Included & Included & Included \\
\hline Year FE & Included & Included & Included \\
\hline GRI Type FE & Included & Included & Included \\
\hline Pseudo R-squared & 0.227 & 0.211 & 0.233 \\
\hline N & 624 & 624 & 624 \\
\hline
\end{tabular}


Table 11. Cont.

\begin{tabular}{|c|c|c|c|c|c|c|c|c|c|c|c|c|}
\hline \multicolumn{13}{|c|}{ Panel B: Second-Stage Regression Model } \\
\hline & \multicolumn{12}{|c|}{ CSRD } \\
\hline & (1) & $(2)$ & (3) & $(4)$ & (1) & $(2)$ & (3) & $(4)$ & $(1)$ & $(2)$ & (3) & $(4)$ \\
\hline & $(-2.27)$ & & & $(-1.93)$ & $(-2.15)$ & & & $(-1.83)$ & $(-2.43)$ & & & $(-2.08)$ \\
\hline TENURE & & $\begin{array}{l}-0.027^{*} \\
(-1.86)\end{array}$ & & $\begin{array}{l}-0.020 \\
(-1.41)\end{array}$ & & $\begin{array}{l}-0.023 \\
(-1.58)\end{array}$ & & $\begin{array}{l}-0.017 \\
(-1.12)\end{array}$ & & $\begin{array}{l}-0.024 \\
(-1.58)\end{array}$ & & $\begin{array}{l}-0.016 \\
(-1.06)\end{array}$ \\
\hline MEETING & & & $\begin{array}{c}0.002 * * * \\
(3.45)\end{array}$ & $\begin{array}{c}0.002 * * * \\
(3.22)\end{array}$ & & & $\begin{array}{c}0.002^{* * *} \\
(3.43)\end{array}$ & $\begin{array}{c}0.002^{* * *} \\
(3.23)\end{array}$ & & & $\begin{array}{c}0.002^{* * *} \\
(3.43)\end{array}$ & $\begin{array}{c}0.002^{* * *} \\
(3.21)\end{array}$ \\
\hline BOARDSIZE & $\begin{array}{c}0.089 * * \\
(2.18)\end{array}$ & $\begin{array}{c}0.088^{* *} \\
(2.14)\end{array}$ & $\begin{array}{c}0.095^{* *} \\
(2.33)\end{array}$ & $\begin{array}{c}0.094^{* *} \\
(2.28)\end{array}$ & $\begin{array}{c}0.106^{* *} \\
(2.45)\end{array}$ & $\begin{array}{c}0.101^{* *} \\
(2.32)\end{array}$ & $\begin{array}{c}0.113 * * * \\
(2.62)\end{array}$ & $\begin{array}{c}0.106^{* *} \\
(2.42)\end{array}$ & $\begin{array}{c}0.094^{* *} \\
(2.38)\end{array}$ & $\begin{array}{c}0.092 * * \\
(2.29)\end{array}$ & $\begin{array}{c}0.100 * * \\
(2.52)\end{array}$ & $\begin{array}{c}0.098^{* *} \\
(2.45)\end{array}$ \\
\hline INDCOM & $\begin{array}{l}-0.000 \\
(-0.67)\end{array}$ & $\begin{array}{l}-0.000 \\
(-0.64)\end{array}$ & $\begin{array}{l}-0.000 \\
(-0.20)\end{array}$ & $\begin{array}{l}-0.000 \\
(-0.29)\end{array}$ & $\begin{array}{l}-0.000 \\
(-0.54)\end{array}$ & $\begin{array}{l}-0.000 \\
(-0.54)\end{array}$ & $\begin{array}{l}-0.000 \\
(-0.08)\end{array}$ & $\begin{array}{l}-0.000 \\
(-0.20)\end{array}$ & $\begin{array}{l}-0.000 \\
(-0.61)\end{array}$ & $\begin{array}{l}-0.000 \\
(-0.60)\end{array}$ & $\begin{array}{l}-0.000 \\
(-0.15)\end{array}$ & $\begin{array}{l}-0.000 \\
(-0.24)\end{array}$ \\
\hline BIG4 & $\begin{array}{l}0.022 \\
(1.19)\end{array}$ & $\begin{array}{l}0.021 \\
(1.14)\end{array}$ & $\begin{array}{l}0.022 \\
(1.21)\end{array}$ & $\begin{array}{l}0.020 \\
(1.09)\end{array}$ & $\begin{array}{l}0.022 \\
(1.22)\end{array}$ & $\begin{array}{l}0.021 \\
(1.18)\end{array}$ & $\begin{array}{l}0.022 \\
(1.25)\end{array}$ & $\begin{array}{l}0.020 \\
(1.12)\end{array}$ & $\begin{array}{l}0.022 \\
(1.20)\end{array}$ & $\begin{array}{l}0.021 \\
(1.16)\end{array}$ & $\begin{array}{l}0.022 \\
(1.22)\end{array}$ & $\begin{array}{l}0.020 \\
(1.10)\end{array}$ \\
\hline FIRMSIZE & $\begin{array}{l}0.004 \\
(0.27)\end{array}$ & $\begin{array}{l}0.006 \\
(0.36)\end{array}$ & $\begin{array}{l}0.007 \\
(0.43)\end{array}$ & $\begin{array}{l}0.009 \\
(0.60)\end{array}$ & $\begin{array}{l}-0.008 \\
(-0.44)\end{array}$ & $\begin{array}{l}-0.004 \\
(-0.22)\end{array}$ & $\begin{array}{l}-0.007 \\
(-0.40)\end{array}$ & $\begin{array}{l}0.000 \\
(0.02)\end{array}$ & $\begin{array}{l}-0.001 \\
(-0.05)\end{array}$ & $\begin{array}{l}0.002 \\
(0.14)\end{array}$ & $\begin{array}{l}0.002 \\
(0.16)\end{array}$ & $\begin{array}{l}0.005 \\
(0.36)\end{array}$ \\
\hline & $(-4.25)$ & $(-4.09)$ & $(-4.02)$ & $(-3.94)$ & $(-3.99)$ & $(-3.94)$ & $(-3.72)$ & $(-3.76)$ & $(-4.17)$ & $(-4.08)$ & $(-3.95)$ & $(-3.90)$ \\
\hline FIRMAGE & $\begin{array}{c}0.062^{* * *} \\
(3.51)\end{array}$ & $\begin{array}{c}0.061^{* * *} \\
(3.45)\end{array}$ & $\begin{array}{c}0.067^{* * *} \\
(3.89)\end{array}$ & $\begin{array}{c}0.064^{* * *} \\
(3.73)\end{array}$ & $\begin{array}{c}0.070^{* * *} \\
(3.71)\end{array}$ & $\begin{array}{c}0.067^{* * *} \\
(3.53)\end{array}$ & $\begin{array}{c}0.076^{* * *} \\
(4.10)\end{array}$ & $\begin{array}{c}0.070^{* * *} \\
(3.72)\end{array}$ & $\begin{array}{c}0.065^{* * *} \\
(3.81)\end{array}$ & $\begin{array}{c}0.064^{* * *} \\
(3.66)\end{array}$ & $\begin{array}{c}0.070 * * * \\
(4.18)\end{array}$ & $\begin{array}{c}0.067^{* * *} \\
(3.97)\end{array}$ \\
\hline LOSS & $\underset{* *}{-0.047}$ & $-0.051^{* * *}$ & $\underset{* *}{-0.049}$ & $-0.051^{* *}$ & $-0.053^{* * *}$ & $\underset{* * *}{-0.055}$ & $\underset{* * *}{-0.056}$ & $\underset{* * *}{-0.055}$ & $-0.050^{* *}$ & $\underset{* * *}{-0.053}$ & $\underset{* * *}{-0.052}$ & $\underset{* * *}{-0.053}$ \\
\hline & $(-2.40)$ & $(-2.61)$ & $(-2.53)$ & $(-2.57)$ & $(-2.60)$ & $(-2.73)$ & $(-2.75)$ & $(-2.67)$ & $(-2.56)$ & $(-2.72)$ & $(-2.68)$ & $(-2.69)$ \\
\hline MILLS & $\begin{array}{l}-0.078 \\
(-1.22)\end{array}$ & $\begin{array}{l}-0.057 \\
(-0.87)\end{array}$ & $\begin{array}{l}-0.063 \\
(-1.00)\end{array}$ & $\begin{array}{l}-0.072 \\
(-1.16)\end{array}$ & $\begin{array}{l}-0.134 \text { * } \\
(-1.80)\end{array}$ & $\begin{array}{l}-0.102 \\
(-1.34)\end{array}$ & $\begin{array}{l}-0.126^{*} \\
(-1.70)\end{array}$ & $\begin{array}{l}-0.112 \\
(-1.47)\end{array}$ & $\begin{array}{l}-0.105 \text { * } \\
(-1.93)\end{array}$ & $\begin{array}{l}-0.074 \\
(-1.32)\end{array}$ & $\begin{array}{l}-0.084 \\
(-1.59)\end{array}$ & $\begin{array}{l}-0.093 * \\
(-1.74)\end{array}$ \\
\hline CONSTANT & $\begin{array}{l}0.058 \\
(0.14)\end{array}$ & $\begin{array}{l}-0.011 \\
(-0.03)\end{array}$ & $\begin{array}{l}-0.334 \\
(-0.80)\end{array}$ & $\begin{array}{l}-0.342 \\
(-0.83)\end{array}$ & $\begin{array}{l}0.371 \\
(0.83)\end{array}$ & $\begin{array}{l}0.241 \\
(0.53)\end{array}$ & $\begin{array}{l}0.022 \\
(0.05)\end{array}$ & $\begin{array}{l}-0.116 \\
(-0.25)\end{array}$ & $\begin{array}{l}0.199 \\
(0.56)\end{array}$ & $\begin{array}{l}0.088 \\
(0.24)\end{array}$ & $\begin{array}{l}-0.214 \\
(-0.59)\end{array}$ & $\begin{array}{l}-0.222 \\
(-0.61)\end{array}$ \\
\hline Industry FE & Included & Included & Included & Included & Included & Included & Included & Included & Included & Included & Included & Included \\
\hline Year FE & Included & Included & Included & Included & Included & Included & Included & Included & Included & Included & Included & Included \\
\hline GRI Type FE & Included & Included & Included & Included & Included & Included & Included & Included & Included & Included & Included & Included \\
\hline R-squared & 0.404 & 0.401 & 0.410 & 0.416 & 0.404 & 0.401 & 0.411 & 0.416 & 0.406 & 0.402 & 0.412 & 0.418 \\
\hline N & 624 & 624 & 624 & 624 & 624 & 624 & 624 & 624 & 624 & 624 & 624 & 624 \\
\hline
\end{tabular}

Note: $\mathrm{t}$ statistics in parentheses. Asterisks denote statistical significance at the $1 \%\left(^{* * *}\right), 5 \%\left(^{(* *}\right)$, or $10 \%\left(^{*}\right)$ levels, respectively. 


\section{Conclusions}

This study investigated whether the CEO characteristics of busyness, tenure, and the frequency of CEO meetings affect the corporate social responsibility (CSR) disclosure in all companies listed on the Indonesia Stock Exchange and the Global Reporting Initiative (GRI) database for the 2010-2018 period. This research showed that companies with busy CEOs or CEOs with long tenure produce less CSR disclosure. This is because busy CEOs tend not to allocate their time and attention optimally to evaluate and understand CSR-related issues and cannot develop strategies appropriately, especially strategies related to corporate CSR disclosure. While CEOs with long tenure tend to avoid risks and feel comfortable in their position, they are reluctant to make changes and are more concerned with their personal goals than achieving the company's sustainability goals. The results of this study also show that companies with CEOs who frequently attend board meetings produce more CSR disclosure. By attending a meeting of the board of directors, CEOs will get more information, ideas, suggestions, and input from the other board of directors to answer various problems and issues related to the company's ever-changing sustainability. This study also provided robust results regarding the endogeneity problems in self-selection bias, both for observable and unobservable variables. In an additional analysis, this study found that company losses weaken the negative relationship between CEO busyness and tenure and CSR disclosure, as well as the positive relationship between CEO meeting frequency and the CSR disclosure.

This study enriches the literature on corporate governance and sustainability reporting. Moreover, it supports the upper echelons theory by explaining that the CEO's characteristics reflect strategic decisions related to the CSR disclosure strategy. Therefore, companies need to consider the activities of the CEO in charge. By considering the level of activity, the company can ensure the resulting performance, especially in this article, is related to CSR disclosure. In practical terms, this research can be an essential source of information for shareholders and companies when it comes to appointing CEOs and determining their roles and responsibilities. Furthermore, for the CSR Rating Agency and the Business Entity Social Responsibility Forum, this study can give some consideration when understanding, assessing, and predicting the level of corporate CSR disclosure.

There are several limitations to this study. First, this study ignored the involvement or input of company stakeholders in measuring CSR disclosure. Second, this study also ignored the sustainability topics in board meetings when measuring the frequency of CEO meetings. Third, this study also ignored the audits of sustainability reports or CSR reports.

Further research may consider the limitations of this research and may add other governance variables related to CSR disclosure, such as the presence of the Chief Sustainability Officer (CSO) and the existence of the CSR committee or sustainability committee in the company, to enrich the evidence, as well as consider using an audited sustainability report. Given that CSR disclosures differ in quality $([86,87])$, further research can investigate the effect of CEO characteristics on the quality of CSR disclosure. Finally, further research can also enrich this current study by linking the results with firm value or firm efficiency using other powerful statistical tools, such as partial least squares structural equation modeling (PLS-SEM).

Author Contributions: Data curation, M.C.R.; Formal analysis, M.C.R., I.H.; Methodology, M.C.R., I.H.; Supervision, I.H.; Writing—original draft, M.C.R.; Writing—review \& editing, I.H., K.A.K. All authors have read and agreed to the published version of the manuscript.

Funding: This work was partially supported by the International Collaboration Research Grant by the Faculty of Economics and Business, Universitas Airlangga, Indonesia.

Institutional Review Board Statement: Not applicable.

Informed Consent Statement: Not applicable.

Data Availability Statement: Not applicable. 
Conflicts of Interest: The authors declare no conflict of interest.

\section{Appendix A}

Table A1. Operational variable definition.

\begin{tabular}{|c|c|c|c|}
\hline Variable & & Measurement & Source \\
\hline Dependent: CSR Disclosure & CSRD & $\begin{array}{l}\text { CSR disclosure score; the total items disclosed } \\
\text { divided by the total items that should be } \\
\text { disclosed based on the type of GRI index used } \\
\text { [78-81] }\end{array}$ & $\begin{array}{l}\text { Sustainability Report } \\
\text { \& Annual Report [82] }\end{array}$ \\
\hline Independent: CEO Busyness & BUSY & $\begin{array}{c}\text { Dummy variable, value of } 1 \text { if the CEO holds } \\
\text { two or more positions, and value of } 0 \text { if } \\
\text { otherwise }\end{array}$ & Bloomberg [83] \\
\hline CEO Tenure & TENURE & $\begin{array}{c}\text { Dummy variable, value of } 1 \text { if the CEO's } \\
\text { tenure is more than five years, and a value of } 0 \\
\text { if otherwise }\end{array}$ & Bloomberg [83] \\
\hline Frequency of CEO Meeting & MEETING & $\begin{array}{c}\text { The number of meetings attended by the CEO } \\
\text { is divided by the maximum number of } \\
\text { meetings held for the company's board of } \\
\text { directors in one year. }\end{array}$ & Annual Report [82] \\
\hline Control: Board Size & BOARDSIZE & $\begin{array}{c}\text { Natural logarithm of the number of boards of } \\
\text { directors and boards of commissioners in a } \\
\text { company }\end{array}$ & Financial Report [82] \\
\hline $\begin{array}{l}\text { Percentage of Independent } \\
\text { Commissioners }\end{array}$ & INDCOM & $\begin{array}{l}\text { Percentage of the number of independent } \\
\text { commissioners compared to the number of } \\
\text { commissioners in the company }\end{array}$ & Financial Report [82] \\
\hline Big Four External Auditor & BIG4 & $\begin{array}{c}\text { Dummy variable, value } 1 \text { if the company is } \\
\text { audited by Big Four auditors, and value } 0 \text { if } \\
\text { otherwise }\end{array}$ & Financial Report [82] \\
\hline Firm Size & FIRMSIZE & Natural logarithm of total assets & ORBIS [84] \\
\hline Leverage Level & LEVERAGE & Total debt divided by total assets & ORBIS [84] \\
\hline Firm Age & FIRMAGE & $\begin{array}{l}\text { Natural logarithm of the number of years since } \\
\text { the company was founded }\end{array}$ & ORBIS [84] \\
\hline Company Losses & LOSS & $\begin{array}{l}\text { Dummy variable, value of } 1 \text { if in the previous } \\
\text { year the company received negative income } \\
\text { after tax, and value of } 0 \text { if otherwise }\end{array}$ & ORBIS [84] \\
\hline $\begin{array}{c}\text { Distance Company Head } \\
\text { Office to Airport }\end{array}$ & DISTANCE & $\begin{array}{c}\text { Natural logarithm of the distance between the } \\
\text { company's head office and the largest airport } \\
\text { in the city where the company headquarters } \\
\text { are located }\end{array}$ & GOOGLE [85] \\
\hline CEO Age $>60$ Years & CEOAGE & $\begin{array}{c}\text { Dummy variable, value of } 1 \text { if the CEO age is } \\
\text { more than or equal to } 60 \text { years and } 0 \text { if } \\
\text { otherwise }\end{array}$ & Annual Report [82] \\
\hline
\end{tabular}

\section{References}

1. Shahin, A.; Zairi, M. Corporate governance as a critical element for driving excellence in corporate social responsibility. Int. J. Qual. Reliab. Manag. 2007, 24, 753-770. [CrossRef]

2. Jamali, D.; Safieddine, A.M.; Rabbath, M. Corporate Governance and Corporate Social Responsibility Synergies and Interrelationships. Corp. Gov. Int. Rev. 2008, 16, 443-459. [CrossRef]

3. Raufflet, E.; Cruz, L.B.; Bres, L. An assessment of corporate social responsibility practices in the mining and oil and gas industries. J. Clean. Prod. 2014, 84, 256-270. [CrossRef]

4. Kaymak, T.; Bektas, E. Corporate Social Responsibility and Governance: Information Disclosure in Multinational Corporations. Corp. Soc. Responsib. Environ. Manag. 2017, 24, 555-569. [CrossRef]

5. Ferrero-Ferrero, I.; Fernández-Izquierdo, M.Á.; Muñoz-Torres, M.J. Integrating Sustainability into Corporate Governance: An Empirical Study on Board Diversity. Corp. Soc. Responsib. Environ. Manag. 2013, 22, 193-207. [CrossRef]

6. Aguilera-Caracuel, J.; Guerrero-Villegas, J. How Corporate Social Responsibility Helps MNEs to Improve their Reputation. The Moderating Effects of Geographical Diversification and Operating in Developing Regions. Corp. Soc. Responsib. Environ. Manag. 2018, 25, 355-372. [CrossRef] 
7. Martínez-Ferrero, J.; Garcia-Sanchez, I.M.; Cuadrado-Ballesteros, B. Effect of financial reporting quality on sustainability information disclosure. Corp. Soc. Responsib. Environ. Manag. 2015, 22, 45-64. [CrossRef]

8. Chang, Y.K.; Oh, W.-Y.; Park, J.H.; Jang, M.G. Exploring the Relationship Between Board Characteristics and CSR: Empirical Evidence from Korea. J. Bus. Ethic. 2017, 140, 225-242. [CrossRef]

9. Michelon, G.; Pilonato, S.; Ricceri, F. CSR reporting practices and the quality of disclosure: An empirical analysis. Crit. Perspect. Account. 2015, 33, 59-78. [CrossRef]

10. MacKenzie, C. Boards, Incentives and Corporate Social Responsibility: The case for a change of emphasis. Corp. Gov. Int. Rev. 2007, 15, 935-943. [CrossRef]

11. Waldman, A.D.; De Luque, M.S.; Washburn, N.; House, R.J.; Adetoun, B.; Barrasa, A.; Bobina, M.; Bodur, M.; Chen, Y.-J.; Debbarma, S.; et al. Cultural and leadership predictors of corporate social responsibility values of top management: A Globe study of 15 countries. J. Int. Bus. Stud. 2006, 37, 823-837. [CrossRef]

12. Ruigrok, W.; Peck, S.I.; Keller, H. Board Characteristics and Involvement in Strategic Decision Making: Evidence from Swiss Companies. J. Manag. Stud. 2006, 43, 1201-1226. [CrossRef]

13. Daft, R.L. The Executive and the Elephant: A Leader's Guide for Achieving Inner Excellence; John Wiley \& Sons: Hoboken, NJ, USA, 2010.

14. Hillman, A.J.; Dalziel, T. Boards of directors and firm performance: Integrating agency and resource dependence perspectives. Acad. Manag. Rev. 2003, 28, 383-396. [CrossRef]

15. Hambrick, D.C.; Mason, P.A. Upper echelons: The organization as a reflection of its top managers. Acad. Manag. Rev. 1984, 9 , 193-206. [CrossRef]

16. Harymawan, I.; Nasih, M.; Ratri, M.C.; Nowland, J. CEO busyness and firm performance: Evidence from Indonesia. Heliyon 2019, 5, e01601. [CrossRef]

17. Fama, E.F.; Jensen, M.C. Agency problems and residual claims. J. Law Econ. 1983, 26, 327-349. [CrossRef]

18. Johnson, R.A.; Greening, D.W. The effects of corporate governance and institutional ownership types on corporate social performance. Acad. Manag. J. 1983, 42, 564-576.

19. De Villiers, C.; Naiker, V.; Van Staden, C.J. The effect of board characteristics on firm environmental perfor-mance. J. Manag. 2011, 37, 1636-1663.

20. Cashman, G.D.; Gillan, S.L.; Jun, C. Going Overboard? On Busy Directors and Firm Value. J. Bank. Financ. 2012, 36, 3248-3259. [CrossRef]

21. Fich, E.M.; Shivdasani, A. Are Busy Boards Effective Monitors? J. Financ. 2006, 61, 689-724. [CrossRef]

22. Core, J.E.; Holthausen, R.W.; Larcker, D.F. Corporate governance, chief executive officer compensation, and firm performance. J. Financ. Econ. 1999, 51, 371-406. [CrossRef]

23. Jiraporn, P.; Davidson, W.N.; Ning, Y.; DaDalt, P.J. Too Busy to Show Up? An Analysis of Directors' Absences. SSRN Electron. J. 2008, 49, 1159-1171. [CrossRef]

24. Mallin, C.A.; Michelon, G. Board reputation attributes and corporate social performance: An empirical inves-tigation of the US best corporate citizens. Account. Bus. Res. 2011, 41, 119-144. [CrossRef]

25. Di Pietra, R.; Grambovas, C.A.; Raonic, I.; Riccaboni, A. The effects of board size and 'busy'directors on the market value of Italian companies. J. Manag. Gov. 2008, 12, 73-91. [CrossRef]

26. Bebchuk, L.A.; Fried, J.M. Pay Without Performance: Overview of the Issues. J. Appl. Corp. Financ. 2005, 17, 8-23. [CrossRef]

27. Krüger, P. Corporate Social Responsibility and the Board of Directors. Job Market Paper; Toulouse School of Economics: Toulouse, France, 2009.

28. Harjoto, A.M.; Laksmana, I.; Lee, R. Board Diversity and Corporate Social Responsibility. J. Bus. Ethic 2015, 132, 641-660. [CrossRef]

29. Huang, S.K. The Impact of CEO Characteristics on Corporate Sustainable Development. Corp. Soc. Responsib. Environ. Manag. 2013, 20, 234-244. [CrossRef]

30. Katmon, N.; Mohamad, Z.Z.; Norwani, N.M.; Al Farooque, O. Comprehensive Board Diversity and Quality of Corporate Social Responsibility Disclosure: Evidence from an Emerging Market. J. Bus. Ethic 2017, 157, 447-481. [CrossRef]

31. Muttakin, M.B.; Khan, A.; Mihret, D.G. The effect of board capital and CEO power on corporate social responsibility disclosures. J. Bus. Ethics 2018, 150, 41-56. [CrossRef]

32. Handajani, L.; Subroto, B.; Sutrisno, T.; Saraswati, E. Does board diversity matter on corporate social disclosure? An Indonesian evidence. J. Econ. Sustain. Dev. 2014, 5, 8-16.

33. Hafsi, T.; Turgut, G. Boardroom Diversity and its Effect on Social Performance: Conceptualization and Empirical Evidence. J. Bus. Ethic 2012, 112, 463-479. [CrossRef]

34. Rutherford, M.A.; Buchholtz, A.K. Investigating the relationship between board characteristics and board in-formation. Corp. Gov. Int. Rev. 2007, 15, 576-584. [CrossRef]

35. Birindelli, G.; Dell'Atti, S.; Iannuzzi, A.P.; Savioli, M. Composition and Activity of the Board of Directors: Impact on ESG Performance in the Banking System. Sustainability 2018, 10, 4699. [CrossRef]

36. Adawi, M.; Rwegasira, K. Corporate boards and voluntary implementation of best disclosure practices in emerging markets: Evidence from the UAE listed companies in the Middle East. Int. J. Discl. Gov. 2011, 8, 272-293. [CrossRef] 
37. Dienes, D.; Velte, P. The Impact of Supervisory Board Composition on CSR Reporting. Evidence from the German Two-Tier System. Sustainability 2016, 8, 63. [CrossRef]

38. Ricart, J.E.; Rodríguez, M.; Sanchez, P. Sustainability in the Boardroom: An Empirical Examination of Dow Jones Sustainability World Index Leaders. SSRN Electron. J. 2005, 5, 24-41. [CrossRef]

39. Laksmana, I. Corporate board governance and voluntary disclosure of executive compensation practices. Contemp. Account. Res. 2008, 25, 1147-1182. [CrossRef]

40. Giannarakis, G. Corporate governance and financial characteristic effects on the extent of corporate social responsibility disclosure. Soc. Responsib. J. 2014, 10, 569-590. [CrossRef]

41. Petersen, M.A. Estimating standard errors in finance panel data sets: Comparing approaches. Rev. Financ. Stud. 2009, 22, 435-480. [CrossRef]

42. Johnson, H.H. Does it pay to be good? Social responsibility and financial performance. Bus. Horizons 2003, 46, 34-40. [CrossRef]

43. Ferris, S.P.; Jagannathan, M.; Pritchard, A.C. Too Busy to Mind the Business? Monitoring by Directors with Multiple Board Appointments. J. Financ. 2003, 58, 1087-1111. [CrossRef]

44. Daily, C.M.; Dalton, D.R. Bankruptcy and corporate governance: The impact of board composition and structure. Acad. Manag. J. 1994, 37, 1603-1617.

45. Falato, A.; Kadyrzhanova, D.; Lel, U. Distracted directors: Does board busyness hurt shareholder value? J. Financ. Econ. 2014, 113, 404-426. [CrossRef]

46. Elsakit, O.M.; Worthington, A.C. The Impact of Corporate Characteristics and Corporate Governance on Corporate Social and Environmental Disclosure: A Literature Review. Int. J. Bus. Manag. 2014, 9, 1-15. [CrossRef]

47. Allegrini, M.; Greco, G. Corporate boards, audit committees and voluntary disclosure: Evidence from Italian Listed Companies. J. Manag. Gov. 2013, 17, 187-216. [CrossRef]

48. Hambrick, D.C.; Geletkanycz, M.A.; Fredrickson, J.W. Top executive commitment to the status quo: Some tests of its determinants. Strat. Manag. J. 1993, 14, 401-418. [CrossRef]

49. Herawaty, V.; Solihah, D. The Effect of CEO Tenure, Managerial Skills and Earning Power on Earnings Manipulation with Corporate Governance as a Moderating Variable on Manufacturing Companies in Indonesia Stock Exchange. Acad. Account. Financ. Stud. J. 2019, 23, 1-16. Available online: https:/ / www.abacademies.org/articles/The-Effect-of-CEO-Tenure-ManagerialSkills-and-Earning-Power-on-Earnings-Manipulation-1528-2635-23-SI-1-355.pdf (accessed on 10 January 2021).

50. Johan, A.P. Ceos Characteristics and the Successful of Turnaround Strategy: Evidences from Indonesia. Acad. Strateg. Manag. J. 2017, 16, 69-80. Available online: https://www.abacademies.org/articles/ceos-characteristics-and-the-successful-of-turnaroundstrategy-evidences-from-indonesia-6524.html (accessed on 10 January 2021).

51. Agustriyana, D.; Tarmidi, D.; Anderson, B.B. CEO power, corporate governance, auditors' reputation, and its effects on corporate islamic bonds rating. Int. J. Psychosoc. Rehabil. 2020, 24, 3339-3349.

52. Chen, X.; Van Staden, C. Stakeholder Pressure, Social Trust, Governance and the Disclosure Quality of Environ-Mental Information; APIRA: Sydney, Australia, 2010.

53. Conger, J.A. Qualitative research as the cornerstone methodology for understanding leadership. Leadersh. Q. 1998, 9, 107-121. [CrossRef]

54. Vafeas, N. Board meeting frequency and firm performance. J. Financ. Econ. 1999, 53, 113-142. [CrossRef]

55. Haniffa, R.; Cooke, T. The impact of culture and governance on corporate social reporting. J. Account. Public Policy 2005, 24, 391-430. [CrossRef]

56. Jizi, M.I.; Salama, A.; Dixon, R.; Stratling, R. Corporate governance and corporate social responsibility disclosure: Evidence from the US banking sector. J. Bus. Ethic. 2014, 125, 601-615. [CrossRef]

57. Hussain, N.; Rigoni, U.; Orij, R.P. Corporate Governance and Sustainability Performance: Analysis of Triple Bottom Line Performance. J. Bus. Ethic. 2018, 149, 411-432. [CrossRef]

58. Tencati, A.; Perrini, F.; Pogutz, S. New Tools to Foster Corporate Socially Responsible Behavior. J. Bus. Ethic. 2004, 53, 173-190. [CrossRef]

59. Gorenak, S.; Bobek, V. Total responsibility management indicators and sustainable development. Int. J. Sustain. Soc. 2010, 2, 248. [CrossRef]

60. Rao, K.; Tilt, C. Board Composition and Corporate Social Responsibility: The Role of Diversity, Gender, Strategy and Decision Making. J. Bus. Ethic. 2016, 138, 327-347. [CrossRef]

61. Gray, R.; Kouhy, R.; Lavers, S. Corporate social and environmental reporting: A review of the literature and a longitudinal study of UK disclosure. Account. Audit. Account. J. 1995, 8, 47-77. [CrossRef]

62. Chou, H.-I.; Chung, H.; Yin, X. Attendance of board meetings and company performance: Evidence from Taiwan. J. Bank. Financ. 2013, 37, 4157-4171. [CrossRef]

63. Khan, I.; Khan, I.; Saeed, B.B. Does board diversity affect quality of corporate social responsibility disclosure? Evidence from Pakistan. Corp. Soc. Responsib. Environ. Manag. 2019, 26, 1371-1381. [CrossRef]

64. Hategan, C.D.; Sirghi, N.; Curea-Pitorac, R.I.; Hategan, V.P. Doing well or doing good: The relationship between corporate social responsibility and profit in Romanian companies. Sustainability 2018, 10, 1041. [CrossRef]

65. Trinh, V.Q.; Elnahass, M.; Salama, A.; Izzeldin, M. Board busyness, performance and financial stability: Does bank type matter? Eur. J. Financ. 2019, 26, 774-801. [CrossRef] 
66. Field, L.; Lowry, M.; Mkrtchyan, A. Are busy boards detrimental? J. Financ. Econ. 2013, 109, 63-82. [CrossRef]

67. Tham, Y.H.; Sultana, N.; Singh, H.; Taplin, R. Busy boards and earnings management-an Australian perspective. Asian Rev. Account. 2019, 27, 464-486. [CrossRef]

68. Ahn, S.; Jiraporn, P.; Kim, Y.S. Multiple directorships and acquirer returns. J. Bank. Financ. 2010, 34, 2011-2026. [CrossRef]

69. Ferris, S.P.; Jayaraman, N.; Liao, M.Y. Labor Market Consequences for Busy Directors: Evidence from Inter-national Mergers and Acquisitions. J. Financ. Res. 2019, 42, 449-489. [CrossRef]

70. Ali, A.; Zhang, W. CEO tenure and earnings management. J. Account. Econ. 2015, 59, 60-79. [CrossRef]

71. Choi, J.H.; Kim, S.; Lee, A. CEO Tenure, Corporate Social Performance, and Corporate Governance: A Korean Study. Sustainability 2019, 12, 99. [CrossRef]

72. Mitra, S.; Song, H.; Lee, S.M.; Kwon, S.H. CEO tenure and audit pricing. Rev. Quant. Financ. Account. 2019, 55, 427-459. [CrossRef]

73. Baccouche, S.; Hadriche, M.; Omri, A. Multiple directorships and board meeting frequency: Evidence from France. Appl. Financ. Econ. 2014, 24, 983-992. [CrossRef]

74. Nowland, J.; Simon, A. Is poor director attendance contagious? Aust. J. Manag. 2017, 43, 42-64. [CrossRef]

75. Wooldridge, J.M. On estimating firm-level production functions using proxy variables to control for unobservables. Econ. Lett. 2009, 104, 112-114. [CrossRef]

76. Chakravarty, S.; Rutherford, L.G. Do busy directors influence the cost of debt? An examination through the lens of takeover vulnerability. J. Corp. Financ. 2017, 43, 429-443. [CrossRef]

77. James, H.L.; Wang, H.; Xie, Y. Busy directors and firm performance: Does firm location matter? N. Am. J. Econ. Financ. 2018, 45, 1-37. [CrossRef]

78. Global Reporting Initiatives. GRI Standards Index. 2017. Available online: https:/ /www.globalreporting.org/how-to-use-thegri-standards/gri-standards-english-language/ (accessed on 10 January 2021).

79. Global Reporting Initiatives. GRI G.4. 2017. Available online: https://www.globalreporting.org/how-to-use-the-gri-standards / gri-standards-english-language/ (accessed on 10 January 2021).

80. Global Reporting Initiatives. GRI G.3.1. 2017. Available online: https:/ / www.globalreporting.org/how-to-use-the-gri-standards / gri-standards-english-language/ (accessed on 10 January 2021).

81. Global Reporting Initiatives. GRI G.3.0 index. 2017. Available online: https://www.globalreporting.org/how-to-use-the-gristandards / gri-standards-english-language/ (accessed on 10 January 2021).

82. Indonesia Stock Exchange. 2019. Available online: https://www.idx.co.id/en-us/listed-companies/financial-statements-annualreport/ (accessed on 10 January 2021).

83. Bloomberg. 2019. Available online: https://www.bloomberg.com/ (accessed on 10 January 2021).

84. Bureau Van Dijk. Orbis. 2019. Available online: https://orbis.bvdinfo.com/version-2021416/orbis/Companies/Login? returnUrl=\%2Fversion-2021416\%2Forbis\%2FCompanies (accessed on 10 January 2021).

85. Google. Google Maps. 2019. Available online: https://www.google.co.id/maps (accessed on 10 January 2021).

86. Brammer, S.; Pavelin, S. Factors influencing the quality of corporate environmental disclosure. Bus. Strategy Environ. 2008, 17, 120-136. [CrossRef]

87. Valor, C.; Zasuwa, G. Quality reporting of corporate philanthropy. Corp. Commun. Int. J. 2017. [CrossRef] 